\title{
DOSES DE NITROGÊNIO PARA MAXIMIZAÇÃO DA PRODUÇÃO DO CAPIM-ELEFANTE CV. GUAÇU NO PERÍODO DAS SECAS
}

\author{
Vicente Paulo Martello \\ ENGENHEIRO AGRÔNOMO
}

Orientador: Prof. Dr. JOAQUIM CARLOS WERNER

\begin{abstract}
Dissertação apresentada à Escola Superior de Agricultura "Luiz de Queiroz", Universidade de São Paulo, para obtenção do título de Mestre em Agronomia, Área de concentração: Ciênica Animal e Pastagens.
\end{abstract}

PIRACICABA

Estado de São Paulo - Brasil

Dezembro - 1999 


\title{
Dados Internacionais de Catalogação na Publicação (CIP) DIVISÃO DE BIBLIOTECA E DOCUMENTAÇÃO - Campus "Luiz de Queiroz"/USP
}

\author{
Martello, Vicente Paulo \\ Doses de nitrogênio para maximizaçāo da produçāo do capim-elefante cv. Guaçu no período \\ das secas / Vicente Paulo Martello. - - Piracicaba, 1999. \\ $46 \mathrm{p}$. \\ Dissertaçāo (mestrado) - Escola Superior de Agricultura Luiz de Queiroz, 1999. \\ Bibliografia \\ 1. Adubaçāo nitrogenada 2. Capim elefante 3. Dosagem 4. Fertilizante nitrogenado 5. \\ Produçāo vegetal I. Título
}

CDD 


\begin{abstract}
À minha companheira Vera e aos meus filhos Pedro e Jorge

DEDICO
\end{abstract}

À minha mãe Thereza e a meu pai Antônio que me deram as condições básicas indispensáveis para que este trabalho pudesse ser realizado

\title{
OFEREÇO
}




\section{AGRADECIMENTOS}

À CATI pela minha liberação para a realização deste curso.

Ao Dr. Joaquim Carlos Werner pela boa vontade na orientação deste trabalho, pelo apoio e conhecimentos transmitidos.

Ao Instituto de Zootecnia do Estado de São Paulo pela aceitação da realização deste trabalho de pesquisa na Estação Experimental de Brotas e pelas análises laboratoriais feitas em Nova Odessa.

À Coordenação de Aperfeiçoamento de Pessoal de Nível Superior, CAPES, pelo aporte de recursos financeiros concedido.

Aos professores Dr. Sila Carneira da Silva, Dr. Umberto Packer, Dr. Valdomiro Miyada e Dr. José Eurico pela atenção e apoio durante o curso.

À Escola Superior de Agricultura "Luiz de Queiroz", pela oportunidade de treinamento.

Ao colega José Narciso Sobrinho, pela amizade sincera, pelo incentivo nas horas críticas e pela ajuda.

Aos pesquisadores da Estação Experimental do Instituto de Zootecnia de Brotas, Vanderley B. O. Leite, Carla Cachioni, Erica Politi Saldanha e Antônio de Pádua Deodato, pelo incentivo e ajuda.

Aos funcionários da Estação Experimental do Instituto de Zootecnia de Brotas, pela ajuda nos trabalhos de campo. 
Às funcionárias da Estação Experimental do Instituto de Zootecnia de Nova Odessa, Verônica e Cristina, pela atenção e amizade.

À pesquisadora científica Maria Tereza Colozza pelo auxílio na realização das análises químicas.

Aos colegas Michelle, Jailson, Moema, Osvaldo, Marcos e Mônica pelo apoio e amizade durante o curso.

A todos os colegas do curso de pós-graduação em Ciência Animal e Pastagens, pela oportunidade de perpetuar valiosas amizades durante a realização do curso de mestrado. 


\section{SUMÁRIO}

Página

RESUMO

VIII

SUMMARY

IX

1 INTRODUÇÃO

2 REVISÃO DE LITERATURA 3

2.1 O capim elefante e seu potencial para produção de forragem 3

2.2 A estacionalidade de produção de forragem 5

2.3 O nitrogênio e sua influência na produção de forragem 8

3 MATERIAL E MÉTODOS 14

3.1 Local, espécie forrageira e solo 14

3.2 Plantio e adubação do experimento anterior 16

$\begin{array}{lll}\text { 3.3 Datas das avaliações e respectivas adubações } & 18\end{array}$

3.4 Avaliação, preparo das amostras e análise estatística 19 
4 RESULTADOS E DISCUSSÃO 21

4.1 Produção de matéria seca $\quad 21$

4.2 Porcentagem de matéria seca 28

4.3 Teores de proteína bruta 30

4.4 Extração de nitrogênio 33

4.4 Altura da planta 36

5 CONCLUSÕES $\quad 38$

REFERENCIAS BIBLIOGRÁFICAS $\quad 39$ 


\title{
DOSES DE NITROGÊNIO PARA MAXIMIZAÇÃO DA PRODUÇÃO DO CAPIM-ELEFANTE CV. GUAÇU NO PERÍODO DAS SECAS
}

\author{
Autor: Vicente Paulo Martello \\ Orientador: Prof. Dr. JoaquimCarlos Werner
}

\section{RESUMO}

Foi conduzido um experimento no Instituto de Zootecnia, em uma área da Estação Experimental de Brotas, SP, em solo classificado como Areias Quartzosas, onde foram avaliadas a produção de matéria seca e a distribuição estacional da forragem produzida no ano, a altura, o teor de proteína e a extração de nitrogênio pelo capim-elefante (Pennisetum purpureum Schum.) cv. Guaçu, durante o período de 7 de março de 1997 a 7 de março de 1998. O delineamento experimental utilizado foi em blocos completos ao acaso, com doze repetições. Os tratamentos utilizados foram quatro doses de nitrogênio: $60,120,180$ e $240 \mathrm{~kg}$ por hectare, na forma de nitrocálcio, aplicadas em março de 1997. As parcelas mediam $6,0 \times 4,8 \mathrm{~m}$, colhendo-se uma área útil de $9,6 \mathrm{~m}^{2}$ $(4,0 \times 2,4 \mathrm{~m})$. Efetuaram-se cinco cortes, nas seguintes datas: 16/05/97, 18/09/97, 20/11/97, 22/01/98 e 07/03/98.

Os resultados obtidos indicaram que a aplicação do nitrogênio no final do período das águas, além de aumentar a produção de matéria seca nos três primeiros cortes (maio, setembro e novembro) e no total anual, aumentou de 27 para $34 \%$ a proporção de forragem produzida no período das secas (cortes de maio + setembro), quando se elevou a adubação nitrogenada de 60 para 240 kg por hectare, respectivamente. A porcentagem de matéria seca do Guaçu não foi afetada pelas doses de nitrogênio aplicadas em março. Os teores de proteína bruta, a altura das plantas e a extração de nitrogênio do Guaçu apresentaram efeito das doses de nitrogênio aplicadas em março nos três primeiros cortes, não sendo afetadas pelas mesmas nos dois últimos cortes. 


\title{
NITROGEN RATES FOR MAXIMIZING ELEPHANTGRASS \\ CV. GUAÇU YIELD IN THE DRY SEASON
}

\author{
Author: Vicente Paulo Martello \\ Adviser: Prof. Dr. JoaquimCarlos Werner
}

\section{SUMMARY}

An experiment was carried out at "Instituto de Zootecnia", in an area of the "Experimental Station of Brotas-SP", in a soil classified as Quartzipsamment, to evaluate dry matter yield and the seasonal distribution of the forage produced along the year, the height, the crude protein content and the extraction of nitrogen by elephantgrass (Pennisetum purpureum Schum.) cv. Guaçu, from March 7, 1997 to March 7, 1998. The experiment was set in a complete randomized block design, with twelve repetitions. The treatments were four nitrogen rates: $60,120,180$ and $240 \mathrm{~kg}$ per hectare, in the nitro-chalk form, applied in March of 1997. The plots measured $6.0 \times 4.8 \mathrm{~m}$, with an useful harvesting area of $9.6 \mathrm{~m}^{2}(4.0 \times 2.4 \mathrm{~m})$. It was effected five cuts along the year, made in the following dates: 05/16/97, 09/18/97, 11/20/97, 01/22/98 and 03/07/98.

The results indicated that the application of nitrogen in the end of the rainy season increasead the dry matter yield in the following first three cuts and in the whole year, and increased from 27 to $34 \%$ the proportion of forage produced in the dry season, when the nitrogen fertilization was increased from 60 to $240 \mathrm{~kg}$ per hectare, respectively. The dry matter percentage of the grass was not affected by the nitrogen rates applied in March. The contents of crude protein, the plant height and the extraction of nitrogen of the grass was positively effected by the nitrogen rates applied in March in the first, second and third cuts after the application. 


\section{INTRODUÇÃO}

A área ocupada por pastagens no Brasil corresponde a cerca de $25 \%$ da área agricultável, explorando basicamente a fertilidade natural do solo. Isto proporciona baixos índices de produtividade, o que não é compativel com os tempos atuais de globalização, que exigem produtos de qualidade superior a custos menores. Uma das formas de reduzir os custos pecuários é através da maior produtividade, com distribuição anual mais uniforme, e melhor qualidade da forragem produzida.

Nesse contexto, o uso do capim-elefante (Pennisetum purpureum Schum.), dado seu vigor, elevada produtividade, capacidade de suporte e viabilidade econômica, tem se constituído em uma das espécies forrageiras de grande importância no Brasil. A espécie pode ser encontrada em todas as regiões do país, e apresenta importância ainda maior na região Sudeste, onde está associada à produção de leite. Seu manejo predominante ainda é como capineira, tanto no período das chuvas como no das secas; porém, devido ao seu grande potencial também sob pastejo, sua utilização como tal vem aumentando.

A aptidão de uma região para produção pecuária está diretamente relacionada com as condições do meio ambiente, que possibilitem o pastejo durante a maior parte do ano. Porém, com raras exceções, todas as regiões do mundo possuem alguma limitação que impossibilita a produção constante das forrageiras durante todo o ano. 
O problema da estacionalidade de produção das plantas é enfatizado tanto no Brasil, como na maioria das regiões do mundo. As plantas forrageiras alternam crescimento vigoroso e altas produçōes nos períodos quentes e úmidos, com baixas taxas de crescimento e baixas produções nos períodos secos e frios do ano.

A baixa produção de forragem durante o periodo das secas, em nosso meio, tem sido apontada como um dos fatores que mais contribui para a baixa produtividade, diminuindo drasticamente a produção de leite e ocasionando perda de peso pelos animais de corte. Entretanto, as dificuldades apresentadas pelo ambiente de clima tropical para obtenção de uma produção de forragem mais uniforme durante 0 ano, podem ser superadas através da utilização de diversas tecnologias existentes. Entre elas destaca-se a utilização da adubação nitrogenada. Ela provoca um aumento substancial na produção de matéria seca e pode também provocar aumento no teor protéico da planta forrageira e alterar a distribuição da produção durante o ano.

O manejo do uso dos fertilizantes nitrogenados, empregando-os em épocas estratégicas, como no final do período de crescimento (início de março no Brasil Central), pode alterar a distribuição de forragem durante $\circ$ ano, sem diminuir a produção total, reduzindo assim a necessidade de produção de alimentos suplementares.

Tendo em vista o que foi exposto, o objetivo deste trabalho foi determinar a dose mais adequada de fertilizante nitrogenado que, aplicada no final do período das chuvas (início de março), produza a melhor resposta do capim-elefante cv. Guaçu na produção de matéria seca e de proteína, no período das secas, melhorando assim a distribuição da produção durante o ano. 


\section{REVISÃO DE LITERATURA}

\subsection{O capim elefante e seu potencial para produção de forragem}

O capim-elefante (Pennisetum purpureum Schum.) possui como centro de origem e diversidade a África Tropical, ocorrendo em áreas com precipitação acima de $1000 \mathrm{~mm}$, sendo seu habitat natural entre $10^{\circ}$ de latitude $\mathrm{N}$ e $20^{\circ}$ de latitude $\mathrm{S}$. No Brasil, foi introduzido em 1920 (Carvalho et al., 1982), sendo, inicialmente, utilizado como capineira para fornecimento como forragem verde picada ou conservada. Desde a sua introdução no Brasil, o capimelefante chamou atenção por seu porte avantajado e grande produção de biomassa, chegando a produzir 80 toneladas de matéria seca por hectare por ano (Ruiz et al., 1992) até 95,4 toneladas, com altas adubações nitrogenadas (Jacques, 1990).

Entre os cultivares novos utilizados, destaca-se o "Guaçu" por ser uma gramínea altamente produtiva, sendo proveniente da Venezuela e introduzida no Instituto de Zootecnia, Nova Odessa-SP, em 1978, sob n. 2383. Este cultivar apresenta porte alto, colmos vigorosos, bastante enfolhado, com folhas verde-escuras, distribuídas desde a base e terminando em forma de leque, com pouco joçal, bom perfilhamento, baixo florescimento, boa tolerância à geada e à seca, boa rebrota e melhor distribuição de produção de forragem ao longo do ano, comparado com outros cultivares (Ghisi et al., 1995).

O capim-elefante é, sem dúvida, uma das espécies vegetais com maior potencial produtivo, encontrando-se disseminado por todo território nacional e, 
apesar de planta típica de regiões tropicais, é também cultivada no Sul do Brasil, mesmo com possibilidade de períodos relativamente mais curtos de crescimento ativo (Jacques, 1990).

Seu uso encontra-se ligado, principalmente, à pecuária leiteira, predominando sua utilização na forma de capineira (Hillesheim, 1994), devido à sua elevada produção (Silveira, 1976). Além de sua produção, são citadas outras características favoráveis, como facilidade de multiplicação, resistência a doenças, a pragas, à seca e ao frio, boa palatabilidade e bom valor nutritivo, quando novo (Mozzer et al., 1986).

Apesar de serem divulgadas inúmeras vantagens para 0 uso de forrageiras em capineiras, com destaque para o capim-elefante, a técnica é considerada difícil, devido à dificuldade de ajustar o corte ao estádio de maturidade da planta (Faria, 1994). Acrescenta-se a isto, a dificuldade no aproveitamento das capineiras para suplementação de forragem de boa qualidade na época seca em conseqüência da acentuada estacionalidade de produção que este capim apresenta (Rolin, 1986).

Embora o uso do capim-elefante sob pastejo venha recebendo impulso, o espaço ocupado por ele como capineira está assegurado, pois, obedecidos alguns aspectos de manejo, é uma das espécies de maior produção de forragem de alta qualidade (Hillesheim, 1994).

Quando se analisa o potencial produtivo do capim-elefante, verifica-se que inúmeros fatores interferem na quantidade de matéria seca colhida. Cultivares, variedades, híbridos, intervalos entre cortes, altura de corte, disponibilidade de nutrientes, água, luz, calor (Carvalho, 1985; Jacques, 1990; Lavezzo, 1992) interferem no acúmulo de matéria seca, justificando assim diferenças marcantes de produção relatadas pela literatura, ou seja, de 10,7 a 80,0 toneladas de matéria seca por hectare por ano conseguidas no Brasil (Lavezzo, 1992). Esses fatores, associados à característica típica de 
estacionalidade de produção de matéria seca causam alguma limitação de utilização do capim-elefante.

São muitos os trabalhos desenvolvidos no Brasil, desde os anos 60, que reforçam a importância do capim-elefante como a gramínea forrageira tropical de maior rendimento. Entre os trabalhos, destaca-se o desenvolvido por Zuniga et al. (1967) cujos resultados apontaram o capim-elefante como o de maior produção de forragem, sendo o cultivar Mineiro, o mais produtivo, com produção em torno de 72 toneladas de matéria seca por hectare. Pereira et al. (1966) indicaram novamente o capim-elefante como o mais produtivo, sendo que os cultivares Mercker, Napier e Mineiro, sobrepujaram os demais cultivares e espécies, com média de produção de massa verde, por corte, de 65 toneladas por hectare. Estudos posteriores, como os de Alcantara et al. (1980), enfatizaram a alta capacidade de produção de forragem do capim-elefante.

\subsection{A estacionalidade de produção de forragem}

Dentre os aspectos desejáveis à utilização de plantas forrageiras, a distribuição uniforme da produção de forragem durante 0 ano pode ser considerada como um dos atributos mais atraentes e cobiçados pelos produtores. A estacionalidade da produção forrageira, um dos graves obstáculos da pecuária de corte e de leite, determina aguda flutuação na alimentação dos bovinos baseada na produção das pastagens. Consequentemente, a produção pecuária apresenta ciclos de safra e entressafra (Gomide, 1990).

A produção deficiente de forragem durante o periodo das secas tem sido apontada como um dos fatores que mais contribui para a baixa produtividade dos rebanhos, sendo responsável pela queda acentuada da produção leiteira esperada e de peso dos animais de corte, em conseqüência da redução na 
capacidade de suporte dos pastos. Esta é, geralmente, estabelecida tomandose como base um período de 12 meses (Faria, 1971). Assim sendo, a estacionalidade interfere na economia da atividade pecuária, tendo em vista que o potencial de produção não pode ser aproveitado devido ao fato de que a lotação tem que ser ajustada em função da época de produção mínima do pasto (Yeo, 1977).

O capim elefante, semelhantemente a outras espécies forrageiras tropicais, apresenta estacionalidade de produção durante o ano. Sua produção está concentrada no período das chuvas, produzindo em torno de $70 \%$ do total anual (Hillesheim, 1994). A pouca produção no periodo das secas está presente tanto no Sul do Brasil, onde o frio é mais intenso, como na região Sudeste, onde o inverno coincide com a seca.

A característica da estacionalidade da produção do capim elefante está ligada ao fato de ser esta uma graminea tropical (C4), o que the confere alta produção, com temperaturas ótimas de crescimento em torno de $30-35^{\circ} \mathrm{C}$, e a paralisação do crescimento ao redor de $10^{\circ} \mathrm{C}$ (Hillesheim, 1994). Paterson (1933), citado por Gonçalez et al. (1977), considerou a precipitação pluviométrica nas regiões de clima tropical como fator estacional de maior influência no crescimento das plantas forrageiras. Posteriormente, Caro Costas \& Vincente-Chandler (1956) acrescentaram que a baixa produção forrageira na estação de seca invernal está relacionada às menores temperaturas, aos dias curtos e à escassez de água.

Qualquer prática que aumente o crescimento das plantas e o uso mais eficiente da luz no processo da fotossintese estará melhorando a eficiência do uso da água (Viets, 1962). Desta forma, em condições de campo, um aumento de duas vezes na produção não implica na utilização de duas vezes mais água, mas sim, no uso mais eficiente da mesma quantidade de água, ou pouca quantidade a mais (Viets, 1962). 
O capim-elefante, sendo uma planta tropical, apresenta taxas de crescimento, na época quente e úmida, 5,4 a 8,6 vezes maiores que as conseguidas em épocas de temperaturas mais baixas e clima seco. Dados de Butter Worth \& Arias (1966), para as condições da Venezuela, refletem taxas de crescimento diário da ordem de 185 a $268 \mathrm{~kg}$ de matéria seca por hectare por dia durante a estação chuvosa e de $100 \mathrm{~kg}$ por hectare por dia na época da seca, sob irrigação. Em Viçosa-MG, Vieira \& Gomide (1968) obtiveram taxas de crescimento médio de $36 \mathrm{~kg}$ de matéria seca por hectare por dia, para os cultivares Mineiro, Taiwan e Porte Rico, no período de abril a julho.

Pedreira \& Mattos (1976) mediram a estacionalidade da produção forrageira do capim-elefante Napier, através das taxas de crescimento e de produção de matéria seca na estação das chuvas e na seca. Os autores observaram que a distribuição da produção de matéria seca foi de $10.028 \mathrm{~kg}$ de matéria seca por hectare no período das chuvas e $2.994 \mathrm{~kg}$ por hectare nas secas, representando 77 e $23 \%$, respectivamente da produção anual. As taxas de crescimento do capim-elefante atingiram seus valores mais elevados em fevereiro (60,6 kg de matéria seca por hectare por dia) e os mais baixos em julho (11 kg por hectare por dia).

Gonçalez et al. (1977) estudando a produtividade de dois cultivares de Pennisetum purpureum durante 0 ano, submetidos a dois níveis de fertilidade, observaram uma produção média de $10.058 \mathrm{~kg}$ de matéria seca por hectare no período das secas e $14.678 \mathrm{~kg}$ por hectare no período das chuvas. Os cultivares apresentaram resposta positiva para aplicação de fertilizantes na estação seca invernal, aumentando sua participação anual de $37 \%$ quando não adubado para $44 \%$, quando adubado.

Gomes et al. (1980), testando duas variedades de capim-elefante, "Merkerón mejicano" e "Selection 1", verificaram que as produções de matéria seca durante o periodo das secas foram 22 e $23 \%$, respectivamente, da produção anual. Hay (1977), citado por Pedreira \& Mattos (1982), trabalhando 
com capim-elefante, obteve produções de matéria seca de 14,46 e 2,53 toneladas por hectare nas estações das chuvas e da seca, respectivamente.

Pedreira \& Mattos (1982), trabalhando com oito cultivares de capimelefante, obtiveram produção média anual de $13.125 \mathrm{~kg}$ de matéria seca, sendo que a produção das secas representou $27,87 \%$ (média dos 8 capins) da produção total do ano. Os autores também determinaram a taxa média de crescimento, que no período de maio-setembro (período frio e seco) equivaleu a $26 \%$ da taxa média de outubro-março (período quente e úmido), enfatizando mais uma vez a acentuada distribuição estacional do crescimento.

\subsection{O nitrogênio e sua influência na produção de forragem}

A produtividade do capim elefante é decorrente, entre outras causas, da fertilidade do solo, sendo o nitrogênio o principal nutriente envolvido nas respostas à adubação (Corsi \& Nussio, 1994). A utilização de adubações, principalmente a nitrogenada, poderia ser melhor empregada para melhorar 0 microclima das plantas forrageiras e, desta maneira, utilizar mais eficientemente luz, água e temperatura, que são reconhecidamente, em maior ou menor grau, limitantes ao desenvolvimento das pastagens no inverno (Corsi, 1973).

O nitrogênio é o principal nutriente para manutenção da produtividade das gramineas forrageiras, sendo o principal constituinte das proteinas que participam ativamente na sintese dos compostos orgânicos que formam a estrutura vegetal. $\dot{E}$, portanto, responsável por características do porte da planta tais como: tamanho das folhas e do colmo, aparecimento e desenvolvimento dos perfilhos, etc. Se há deficiência de nitrogênio no solo, o crescimento é lento, as plantas ficam de porte pequeno, com poucos perfilhos, 
e o teor de proteína torna-se deficiente para atendimento das exigências do animal (Werner, 1986).

Martins \& Fonseca (1994) relataram, baseados em vários autores, que o nitrogênio, apesar de abundante na atmosfera, na maioria dos solos apresentase com baixo teor, preponderantemente na forma orgânica, sendo necessário, para sua liberação e absorção pelas plantas, que haja mineralização.

A decomposição de matéria orgânica é regulada, principalmente, pela relação carbono/nitrogênio $(\mathrm{C} / \mathrm{N})$, fazendo com que haja imobilização ou liberação de nitrogênio pelos microorganismos. A mineralização, normalmente, não é limitada pela falta de microorganismos, mas pode ser retardada, desde que haja decréscimo na atividade destes, por fatores de baixa temperatura e falta ou excesso de água. O produto final da mineralização é amônio, que pode ser oxidado a nitrito ou nitrato. Essa fase é chamada de nitrificação, e é efetuada por bactérias autotróficas que utilizam energia de sais orgânicos e carbono do gás carbônico do ar (Martins \& Fonseca, 1994).

Como a velocidade de crescimento nos períodos da primavera e verão é muito grande em nossas condiçōes, mesmo em solos com elevado teor de matéria orgânica, sua decomposição nem sempre é suficiente para liberar o nitrogênio necessário ao máximo crescimento das gramíneas. Por outro lado, em períodos de falta de calor e/ou umidade, a decomposição da matéria orgânica diminui grandemente, ou praticamente cessa, ocorrendo então deficiência de nitrogênio, mesmo em solos ricos em matéria orgânica (Werner, 1986).

A melhor maneira de quantificar o efeito do nitrogênio aplicado em pastagens é com o aumento na produção de matéria seca. Assim, aliando-se a alta produtividade de forragem com alta qualidade, torna-se possivel a obtenção de elevado nível de desempenho por animal acompanhado de aumentos na lotação por hectare (Corsi \& Nussio, 1994). 
Pastagens de gramíneas forrageiras, quando adubadas com doses crescentes de nitrogênio, aumentam linearmente até certos limites, a produção de matéria seca e de proteína. De modo geral, as gramíneas tropicais apresentam resposta à adubação nitrogenada até doses de $1600 \mathrm{~kg}$ por hectare por ano, embora a eficiência de utilização seja reduzida a partir de 300 kg de nitrogênio por hectare por ano (Malavolta et al., 1974).

Vicente-Chandler et al. (1959) obtiveram respostas lineares até doses entre 400 e $800 \mathrm{~kg}$ de nitrogênio por hectare, dependendo do intervalo de cortes. Os autores também avaliaram a recuperação do nitrogênio aplicado, verificando que aplicação de $200 \mathrm{~kg}$ de nitrogênio por hectare por ano propiciou uma recuperação de $44,5 \%$ do nitrogênio aplicado, com produção de $15.213 \mathrm{~kg}$ de matéria seca por hectare por ano e $8,9 \%$ de proteína bruta, para um intervalo de corte de 40 dias. Passando para um intervalo de 60 dias, obtiveram $63,8 \%$ de recuperação de nitrogênio, com produção de 24.617 kg de matéria seca por hectare por ano e 7,2\% de proteína bruta.

Em outro experimento, Vicente-Chandler (1973) relatou que a produção de matéria seca do Napier aumentou rapidamente até doses de nitrogênio de $896 \mathrm{~kg}$ por hectare por ano quando não havia limitação dos demais nutrientes. O teor de proteína bruta também aumentou até a dose mais alta testada (896 $\mathrm{kg}$ ), chegando a $10 \%$ de proteína bruta.

Segundo Corsi \& Nussio (1994), os teores de proteína aumentam de maneira distinta, dependendo do período de descanso da planta, sendo os períodos mais longos aqueles cuja elevação do teor de proteína bruta é menos acentuada. Este fato deve-se a condições de um maior período para a planta metabolizar a fração ntirogenada em produção de matéria seca, provocando o efeito diluição. Em vista disso, as respostas às adubações nitrogenadas, em relação ao aumento de proteína dependerão do período de tempo e/ou condições para o metabolismo. Entretanto, obtém-se, através das adubações nitrogenadas, melhora na qualidade de matéria seca, mesmo sem aumentar o 
teor de proteína bruta, devido a maior produção de massa foliar, perfilhos novos e longevidade das folhas, o que propicia um maior consumo voluntário de forragem.

De acordo com Monteiro (1990), a recomendação da época de adubação nitrogenada para o capim-elefante, submetido a corte, está condicionada ao esquema de utilização da forragem, incentivando uma exaltação da produção na época das chuvas ou das secas. Dessa forma, conforme Werner (1970/71), técnicas de manejo, como a adubação, podem ser empregadas com a finalidade de se obter melhor distribuição da produção de forragens durante 0 ano, sendo a fertilização nitrogenada a de maior importância.

Estudos de Quinn et al. (1961), com pastoreio em capim colonião, no Noroeste do Estado de São Paulo, concluíram que a produção de carne por hectare, a lotação, o ganho diário por novilho e a produção de nutrientes digestíveis totais por hectare, dos pastos, eram maiores quando o nitrogênio era aplicado na estação seca de inverno (maio ou junho) do que quando aplicado na estação úmida de verão (novembro).

Visando uma menor defasagem na produção entre verão e inverno na Austrália, Loneregan (1964) mencionou que a adubação nitrogenada durante o período de inverno, quando a mineralização do nitrogênio orgânico é vagarosa, forneceu aumentos lucrativos de produção mesmo em pastagens consorciadas.

Em experimento conduzido durante um ano com quatro gramíneas tropicais em Sertãozinho, Lima et al. (1968), usando novilhos da raça Gir com 24 meses de idade, obtiveram, para o capim-elefante cv. Napier, aumento no ganho de peso vivo, no período de abril a outubro, de 31 para $93 \mathrm{~kg}$ por hectare, respectivamente para pastos não adubados com nitrogênio e pastos adubados com $200 \mathrm{~kg}$ de nitrogênio por hectare aplicados em três parcelas (março, maio e setembro). 
Pereira et al. (1966) estudando o efeito da irrigação e da adubação na produção dos capins gordura (Melinis minutiflora), sempre verde (Panicum maximum Jacq.) e pangola (Digitaria decumbens Stent), verificaram que, durante o período de maio a outubro, houve aumentos de produção de massa verde proporcionados pelos tratamentos, em relação à testemunha, de tal forma que a irrigação incrementou a produção em $26 \%$ e a adubação nitrogenada, $20 \mathrm{~kg}$ por hectare, em $32 \%$.

Por outro lado, Werner (1970/71) estudou diversas épocas de utilização de adubação nitrogenada para o capim-colonião (Panicum maximum Jacq.) submetido a cortes. Verificou que, embora a produção total anual de matéria seca fosse similar para as diversas épocas de adubação, a aplicação do nitrogênio em uma só vez, em março, resultava nos maiores percentuais de produção de matéria seca no periodo das secas sobre o total anual. Em contrapartida, quando o nitrogênio era todo aplicado em setembro, novembro ou janeiro ocorria a maior concentração da produção de matéria seca do capim no período das chuvas, com baixas produções no período das secas.

Boin et al. (1974), em estudo sobre rendimento e manejo de capineira de capim-elefante cv. Napier, visando obter rendimentos médios de matéria seca durante o período seco (junho a setembro), avaliou rebrotas de cortes efetuados em 28/02, 21/03, 11/04 e 02/05, durante 1967 e 1968, e concluiu que o rendimento médio do corte efetuado em 28/02 foi aproximadamente 2,3 vezes superior ao corte efetuado em 21/03. Os rendimentos dos dois cortes realizados em 11/04 e 02/05 foram tão pequenos que não poderão ser considerados como alternativa visando disponibilidade de forragem verde durante a seca. As médias de produção de matéria seca em $\mathrm{kg}$ por hectare foram: $2.303,1.005,366$ e 358 para as rebrotas dos cortes efetuados em 28/02, 21/03, 11/04 e 02/05, respectivamente. Essa média corresponde ao período de 2 anos de avaliações e cortes efetuados em 18/06, 16/07, 14/08 e 
12/09. Ressalta-se que a adubação nitrogenada efetuada foi relativamente baixa e praticamente concentrada no período de verão.

Lourenço et al. (1978), comparando o efeito de três doses de adubação nitrogenada $(50,100,150 \mathrm{~kg}$ de nitrogênio por hectare), em uma única aplicação feita no final do período chuvoso (março-abril) e um tratamento onde o capim-elefante cv. Napier foi consorciado com Centrosema pubescens Benth e Macropitilium atropurpureum D.C. cv. Siratro, verificaram que à medida que se aumentava a adubação nitrogenada dentro dos limites utilizados ocorreram aumentos significativos nos ganhos de peso vivo por hectare e na capacidade de suporte, tanto para o período das águas quanto para o período das secas, contribuindo para elevar a produção do capim-elefante cv. Napier no período das secas, que corresponde ao período do ano menos favorável ao crescimento de plantas. Além disso, resultou em maior aumento da proporção da produção animal no período das secas em relação ao total anual, à medida que se aumentava a adubação nitrogenada.

Segundo Carvalho et al. (1975), a aplicação de $100 \mathrm{~kg}$ de nitrogênio, $100 \mathrm{~kg}$ de $\mathrm{P}_{2} \mathrm{O}_{5}$ e $50 \mathrm{~kg}$ de potássio por hectare, no período das secas, propiciou $36 \%$ de aumento de rendimento forrageiro de dois cultivares de capim-elefante no período das secas, que passou de 2,18 para 2,96 toneladas por hectare, sob irrigação. 


\section{MATERIAL E MÉTODOS}

\subsection{Local, espécie forrageira e solo}

O experimento foi conduzido no Instituto de Zootecnia, em uma área da Estação Experimental de Brotas, SP, localizada a uma altitude de 650 metros, latitude de $22^{\circ} 16^{\prime} \mathrm{S}$ e longitude de $48^{\circ} 07^{\prime} \mathrm{O}$. O solo do local é classificado como Areias Quartzosas, cujo resultado das análises químicas em diferentes épocas está apresentado na Tabela 1.

De acordo com a classificação de Köppen, o clima da região de Brotas pode ser incluído no Cwa (tropical de altitude, com inverno seco e verão quente). Os dados de precipitação e temperaturas máximas e mínimas mensais dos últimos anos estão apresentados nas Tabelas 2 e 3, respectivamente.

Foi utilizada como espécie de gramínea forrageira o capim-elefante (Pennisetum purpureum Schum.), cultivar Guaçu, no período de 07 de março de 1997 a 07 de março de 1998. 
Tabela 1. Características químicas do solo utilizado no experimento.

\begin{tabular}{|c|c|c|c|c|c|c|c|c|c|}
\hline \multirow[t]{2}{*}{ Época } & $\mathrm{pH}$ & M.O & $\mathrm{P}$ & K & $\mathrm{Ca}$ & $\overline{M g}$ & SB & $\mathrm{T}$ & \multirow{2}{*}{$\begin{array}{l}\mathrm{V} \\
\%\end{array}$} \\
\hline & $\mathrm{CaCl}_{2}$ & $\mathrm{~g} \mathrm{dm}^{-3}$ & $\mathrm{mg} \mathrm{dm}$ & & 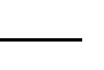 & $\mathrm{mmol}_{\mathrm{c}} \mathrm{dr}$ & & & \\
\hline Jan & 3 & 0 & & 1,10 & 2,0 & 1,0 & 4,00 & 0 & 7,0 \\
\hline $\operatorname{Jan} 9$ & 4,58 & 8 & 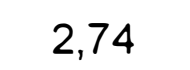 & 0,78 & 10,0 & 4,80 & 18,50 & 62,00 & 29,34 \\
\hline Set 97 & נינ, & 2,5 & 56 & 0,71 & 7,27 & 3,76 & 75 & 50,67 & 26,7 \\
\hline
\end{tabular}

Tabela 2. Médias mensais de precipitação pluviométrica $(\mathrm{mm})$ na região de Brotas, SP.

\begin{tabular}{lcccc}
\hline Mês & 1996 & 1997 & 1998 & Média (1992-1998) \\
\hline Janeiro & 362 & 341 & 223 & 276 \\
Fevereiro & 122 & 213 & 320 & 298 \\
Março & 218 & 70 & 133 & 172 \\
Abril & 104 & 71 & 71 & 97 \\
Maio & 50 & 92 & 127 & 87 \\
Junho & 20 & 205 & 16 & 52 \\
Julho & - & 30 & 15 & 28 \\
Agosto & 18 & - & 26 & 14 \\
Setembro & 166 & 102 & 106 & 98 \\
Outubro & 163 & 106 & 155 & 135 \\
Novembro & 150 & 340 & 65 & 158 \\
Dezembro & 226 & 177 & 386 & 232 \\
\hline Total & 1599 & 1747 & 1643 & 1649 \\
\hline
\end{tabular}


Tabela 3. Médias das temperaturas máximas e mínimas $\left({ }^{\circ} \mathrm{C}\right)$ na região de Brotas, SP.

\begin{tabular}{lcccccccc}
\hline \multirow{2}{*}{ Mês } & \multicolumn{2}{c}{1996} & \multicolumn{2}{c}{1997} & \multicolumn{2}{c}{1998} & \multicolumn{2}{c}{ Média (92-98) } \\
\cline { 2 - 8 } & Máx. & Mín. & Máx. & Mín. & Máx. & Mín. & Máx. & Mín. \\
\hline Janeiro & 35,1 & 20,6 & 32,7 & 18,2 & 37,5 & 13,2 & 35,1 & 17,3 \\
Fevereiro & 37,6 & 21,2 & 33,3 & 16,0 & 35,8 & 15,6 & 35,6 & 17,6 \\
Março & 36,8 & 19,7 & 35,1 & 13,8 & 36,9 & 15,9 & 36,3 & 16,4 \\
Abril & 33,3 & 18,2 & 34,9 & 12,9 & 34,3 & 13,3 & 34,2 & 14,8 \\
Maio & 31,6 & 16,9 & 30,6 & 11,0 & 31,2 & 11,8 & 31,1 & 13,2 \\
Junho & 30,1 & 14,4 & 26,7 & 11,0 & 28,9 & 9,6 & 28,6 & 11,7 \\
Julho & 28,0 & 9,3 & 32,7 & 10,9 & 32,3 & 11,3 & 31,0 & 11,4 \\
Agosto & 33,9 & 11,8 & 32,8 & 11,7 & 31,5 & 10,6 & 32,7 & 11,4 \\
Setembro & 29,4 & 12,2 & 33,1 & 11,5 & 30,8 & 10,3 & 31,1 & 11,3 \\
Outubro & 34,2 & 12,4 & 32,2 & 13,4 & 31,2 & 10,6 & 32,5 & 12,1 \\
Novembro & 35,1 & 15,2 & 34,9 & 11,6 & 35,3 & 15,7 & 35,1 & 14,2 \\
Dezembro & 33,1 & 17,1 & 36,7 & 12,3 & 36,2 & 16,3 & 35,3 & 15,2 \\
\hline
\end{tabular}

\subsection{Plantio e adubação do experimento anterior}

O experimento foi conduzido em área de capim-elefante já existente, com área total de $2.368,8 \mathrm{~m}^{2}$, na qual foi conduzido um experimento anterior, de setembro de 1993 a setembro de 1995. Em novembro de 1992, essa área foi submetida à calagem, utilizando-se 3 toneladas de calcário dolomítico por hectare. A incorporação do calcário e preparo do solo foi feita através de grade aradora e posteriormente grade niveladora.

O plantio ocorreu em 21 de janeiro de 1993, em sulcos de 0,15 metros de profundidade, espaçados de 0,6 metros, através de colmos inteiros e 
desfolhados, deitados em duas fileiras no sulco (pé com ponta) e a seguir cortados em toletes com duas a três gemas. A adubação fosfatada de plantio foi de $50 \mathrm{~kg}$ de $\mathrm{P}_{2} \mathrm{O}_{5}$ por hectare, através do superfosfato triplo. Decorridos 40 dias após o plantio, foi aplicado $50 \mathrm{~kg}$ de nitrogênio (uréia) e $25 \mathrm{~kg}$ de $\mathrm{K}_{2} \mathrm{O}$ (cloreto de potássio) por hectare.

Naquele experimento anterior estudou-se a produção de matéria seca do capim elefante submetido a 4 niveis de adubação nitrogenada (50, 100, 200 e $400 \mathrm{~kg}$ de nitrogênio por hectare por ano) e 3 freqüências de corte $(2,3$ e 4 cortes por ano), num fatorial $4 \times 3$, em delineamento de blocos completos ao acaso, com 4 repetições. As parcelas utilizadas mediam de $6,0 \times 4,8 \mathrm{~m}$, espaçadas $2 \mathrm{~m}$, perfazendo um total de 48 parcelas.

Após o término daquele experimento (setembro de 1995), até o início de março de 1997, o capim elefante foi submetido a cortes em janeiro, outubro e dezembro de 1996, através de facão, a 0,10 m do solo. Após o corte de janeiro de 1996, foi realizada análise de solo, sendo a seguir aplicado à lanço, sem incorporação, 2 toneladas por hectare de calcário dolomítico. Após 30 dias foi aplicado $50 \mathrm{~kg}$ de $\mathrm{P}_{2} \mathrm{O}_{5}$ como superfosfato simples, $90 \mathrm{~kg}$ de $\mathrm{K}_{2} \mathrm{O}$ como cloreto de potássio e $50 \mathrm{~kg}$ de nitrogênio como nitrocálcio, por hectare. Em outubro foram aplicados $50 \mathrm{~kg}$ de nitrogênio ( $30 \mathrm{~kg}$ na forma de nitrocálcio e $20 \mathrm{na}$ forma de fosfato monoamônio), $104 \mathrm{~kg}$ de $\mathrm{P}_{2} \mathrm{O}_{5}$ (fosfato monoamônio) e $150 \mathrm{~kg}$ de $\mathrm{K}_{2} \mathrm{O}$ (cloreto de potássio) por hectare. Em dezembro de 1996, as parcelas foram cortadas e novamente adubadas com $280 \mathrm{~kg}$ de $\mathrm{K}_{2} \mathrm{O}$ (cloreto de potássio) e $50 \mathrm{~kg}$ de nitrogênio (nitrocálcio) por hectare.

A coleta de dados para a presente dissertação iniciou-se em 7 de março de 1997, data em que foi realizado um corte de igualação, com facão a 0,10 m do solo, procedendo-se então a aplicação das doses de nitrogênio correspondentes aos tratamentos estudados. Além das doses de nitrogênio, todas as parcelas receberam uma adubação potássica de $316 \mathrm{~kg}$ de $\mathrm{K}_{2} \mathrm{O}$ (cloreto de potássio) por hectare. 
O experimento foi desenvolvido obedecendo um delineamento em blocos ao acaso, com 12 repetições. Os tratamentos compreenderam 4 doses de nitrogênio: 60, 120, 180 e $240 \mathrm{~kg}$ por hectare, aplicados na forma de nitrocálcio. Os tratamentos foram sorteados de forma dirigida nas 48 parcelas existentes, sendo que cada uma das 4 repetições da combinação dos 4 niveis de nitrogênio e das 3 freqüências de corte do experimento anterior constituiram os novos blocos (12) do trabalho desta dissertação, com o objetivo de tirar 0 efeito dos tratamentos anteriores.

\subsection{Datas das avaliações e respectivas adubações}

Os cortes experimentais foram em número de cinco, no período de março de 1997 a março de 1998, conforme apresentado na Tabela 4. Todos foram efetuados com facão e a $0,10 \mathrm{~m}$ do solo, sendo avaliada a produção de uma área útil de $4,0 \times 2,4 \mathrm{~m}\left(9,6 \mathrm{~m}^{2}\right)$ em cada parcela.

O material coletado no primeiro e segundo cortes foi considerado a produção do período das secas. A produção do terceiro corte foi considerada como intermediária, entre a produção das secas e das chuvas. O material do quarto e quinto cortes foi considerado a produção do período das chuvas. Após o terceiro e quarto cortes foi efetuada uma adubação de reposição igual para todas as parcelas (Tabela 4). 
Tabela 4. Datas dos cortes do capim-elefante e respectivas adubações.

\begin{tabular}{lll}
\hline Cortes & Data & Adubação Posterior ao Corte \\
\hline Igualação & $07 / 03 / 1997$ & $60-120-180-240 \mathrm{~kg} \mathrm{de} \mathrm{N} \mathrm{ha}^{-1}+316,66 \mathrm{~kg} \mathrm{de} \mathrm{K}_{2} \mathrm{O} \mathrm{ha}{ }^{-1}$ \\
$1^{\circ}$ corte & $16 / 05 / 1997$ & Sem adubação \\
$2^{\circ}$ corte & $18 / 09 / 1997$ & Sem adubação \\
$3^{\circ}$ corte & $20 / 11 / 1997$ & $60 \mathrm{~kg}$ de N, $50 \mathrm{~kg} \mathrm{de} \mathrm{P}_{2} \mathrm{O}_{5}$ e $84,62 \mathrm{~kg} \mathrm{de} \mathrm{K}_{2} \mathrm{O} \mathrm{ha}{ }^{-1}$ \\
$4^{\circ}$ corte & $22 / 01 / 1998$ & $60 \mathrm{~kg}$ de N e $206 \mathrm{~kg} \mathrm{de} \mathrm{K}_{2} \mathrm{O} \mathrm{ha}^{-1}$ \\
$5^{\circ}$ corte & $07 / 03 / 1998$ & -- \\
\hline
\end{tabular}

\subsection{Avaliação, preparo das amostras e análise estatística}

Nas respectivas datas de corte, foram efetuadas as medidas das alturas das plantas (média de cada parcela), tomando-se por base as curvaturas das folhas superiores e uma leitura em cada parcela.

Todo o material verde colhido da área útil das parcelas foi pesado no próprio local, e uma amostra representativa de cada parcela foi picada e colocada a secar em estufa com circulação forçada de ar, a $65^{\circ} \mathrm{C}$, até peso constante. Após secas, as amostras foram pesadas, moídas e encaminhadas ao laboratório do Instituto de Zootecnia em Nova Odessa, para determinação dos teores de matéria seca $\left(105^{\circ} \mathrm{C}\right)$ e de nitrogênio total, segundo metodologia descrita por Sarruge \& Haag (1974).

O teor de proteína bruta foi calculado multiplicando-se o teor de nitrogênio total no tecido por 6,25.

Calculou-se a quantidade de nitrogênio extraída pelas plantas em cada corte, multiplicando-se o teor de nitrogênio da planta pela produção de matéria seca por hectare e dividindo-se por cem. 
Os dados foram submetidos à análise de variância e, em função do nível de significância no teste $F(P<0,05)$ para doses de nitrogênio aplicadas, efetuou-se o estudo de regressões polinomiais. $O$ modelo matemático adotado foi: $Y_{i j}=m+a_{i}+b_{j}+e_{i j}$, onde:

$$
\begin{aligned}
& Y=\text { variáveis dependentes analisadas; } \\
& \mathrm{m}=\text { média geral; } \\
& a_{i}=\text { efeito da dose de nitrogênio } i \quad i=1,2,3 \text { e } 4 \text {; } \\
& b_{j}=\text { efeito do bloco } j \quad j=1,2, \ldots, 12 \text {; } \\
& e_{i j}=\text { erro aleatório associado a cada observação ij. }
\end{aligned}
$$




\section{RESULTADOS E DISCUSSÃO}

\subsection{Produção de matéria seca}

As produções de matéria seca do capim-elefante cv. Guaçu, dos cinco cortes e do total anual, em função das doses de nitrogênio aplicadas em março são apresentadas na Tabela 5.

Tabela 5. Produção de matéria seca do Guaçu, nos cinco cortes e no total anual, em função das doses de nitrogênio aplicadas em março.

\begin{tabular}{ccccccc}
\hline $\begin{array}{c}\text { Doses } \\
\text { de N }\end{array}$ & $\begin{array}{c}1^{\circ} \text { corte } \\
16 / 05 / 97\end{array}$ & $\begin{array}{c}2^{\circ} \text { corte } \\
18 / 09 / 97\end{array}$ & $\begin{array}{c}3^{\circ} \text { corte } \\
20 / 11 / 97\end{array}$ & $\begin{array}{c}4^{\circ} \text { corte } \\
22 / 01 / 98\end{array}$ & $\begin{array}{c}5^{\circ} \text { corte } \\
07 / 03 / 98\end{array}$ & Total \\
\hline kg ha $^{-1}$ & & & & & \\
60 & 3569,1 & 1869,7 & 2328,9 & 7519,8 & 4682,0 & 19969 \\
120 & 4585,5 & 2438,2 & 2881,4 & 7266,9 & 4981,0 & 22153 \\
180 & 5456,8 & 2540,1 & 3194,8 & 7715,3 & 4948,0 & 23855 \\
240 & 5815,3 & 2941,4 & 4151,3 & 7678,0 & 4780,0 & 25366 \\
Reg Lin. & $\star \star$ & $\star \star$ & $\star \star$ & n.s. & n.s. & $\star \star$ \\
Reg Quad. & n.s. & n.s. & n.s. & n.s. & n.s. & n.s. \\
\hline C.V. (\%) & 11,91 & 13,43 & 19,72 & 22,07 & 14,13 & 12,96 \\
\hline
\end{tabular}

${ }^{\star}$, n.s.: significativo a $1 \%$ e não significativo pelo teste $F$, respectivamente. 
A análise de variância para a produção de matéria seca do Guaçu mostrou diferença significativa $(P<0,01)$ entre doses para o primeiro, segundo, terceiro cortes e total anual. As produções de matéria seca desses cortes (Figura 1) e do total anual, em função das doses de nitrogênio adequaram-se ao modelo linear de regressão. A produção total anual se adequou a seguinte equação: $\quad Y=18279,25+30,6538 X \quad\left(R^{2}=0,99^{\star \star}\right.$. $)$

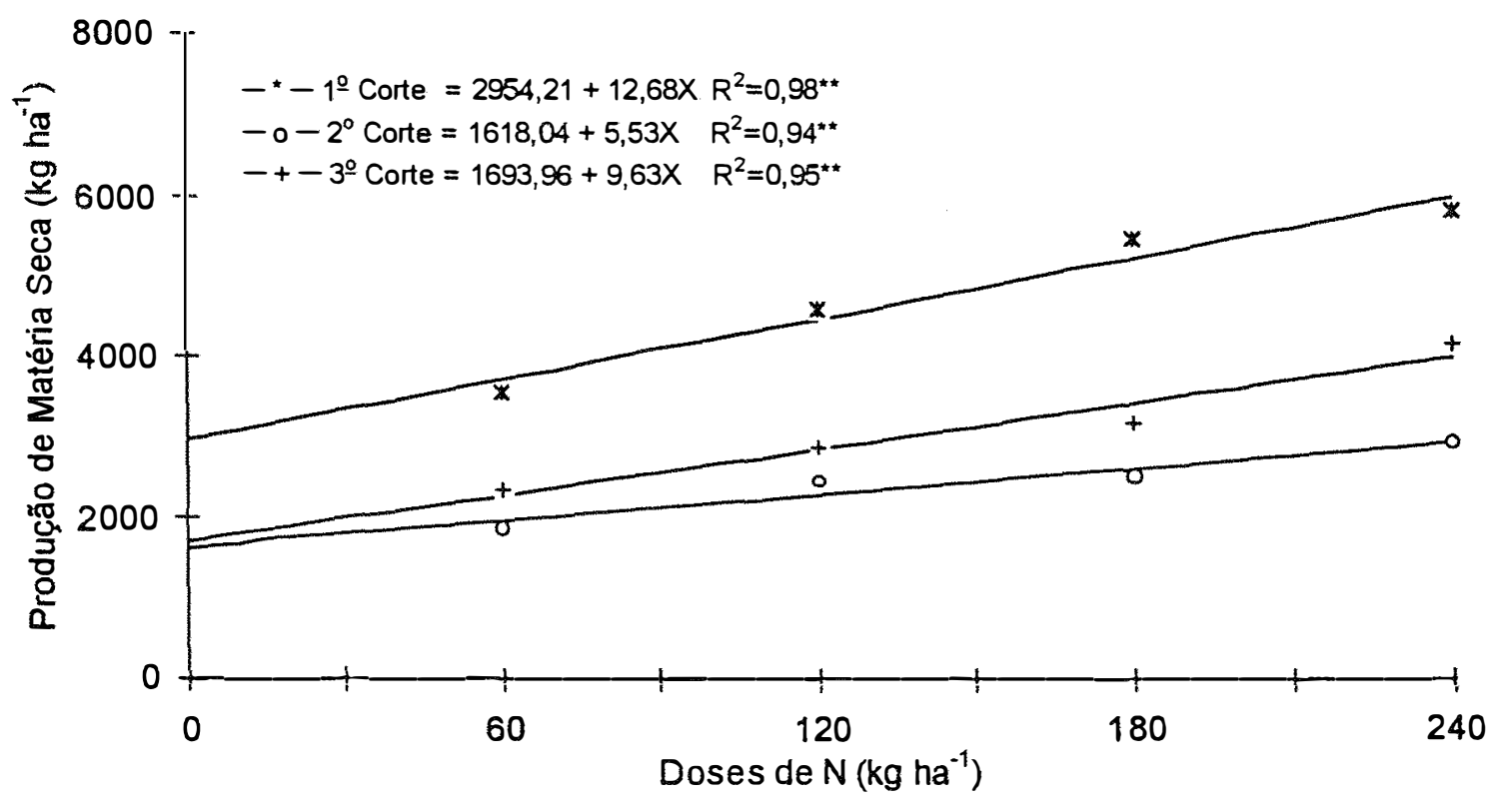

Figura 1. Produção de matéria seca do Guaçu no primeiro, segundo e terceiro cortes, em função das doses de nitrogênio aplicadas em março.

Pode-se observar na Figura 1 que a resposta mais acentuada foi atingida no primeiro corte (maio de 1997), uma vez que as condições climáticas após a aplicação das doses de nitrogênio (em março de 1997) e até o primeiro corte ainda se apresentavam favoráveis. A produção de matéria seca do segundo corte, realizado no início de setembro, apresentou os menores valores, mas ainda assim com resposta linear às doses de nitrogênio aplicadas em março, apesar da precipitação reduzida durante o período invernal, 
associada às temperaturas mais baixas durante este período. Por ocasião do terceiro corte (novembro de 1997), a produção de matéria seca elevou-se novamente, em razão do aumento da temperatura e da precipitação pluviométrica (dados já mostrados nas Tabelas 2 e 3) e continuou a apresentar resposta linear às doses de nitrogênio aplicadas em março, refletindo efeito residual bastante prolongado da adubação nitrogenada aplicada naquele mês. Este fato é de grande relevância porque o início da primavera, nas condições do Brasil Central, é um período crítico de falta de disponibilidade de forragem nos sistemas baseados em pastagens.

As produções de matéria seca do quarto e quinto cortes não foram influenciadas significativamente pelas doses de nitrogênio aplicadas em março, mostrando que o adubo aplicado nesta época já não apresentava mais efeito residual a partir do terceiro corte, efetuado em novembro de 1997. Entretanto, verifica-se que as produções de matéria seca apresentaram-se, de modo geral, mais elevadas nesses dois cortes, os quais foram efetuados, respectivamente em janeiro e março de 1998, época em que as condições climáticas são mais favoráveis ao crescimento do capim. Além disso, foram realizadas, em todos os tratamentos, adubações iguais com nitrogênio $(60 \mathrm{~kg}$ por hectare, após o terceiro e quarto cortes), que também contribuíram para a obtenção das mais elevadas produções de matéria seca.

Pacciullo (1997) relatou decréscimos nos rendimentos forrageiros com o suceder dos cortes do capim-elefante adubado com doses de nitrogênio variando de 0 a $300 \mathrm{~kg}$ por hectare, o que, conforme o autor evidencia a progressiva perda da fertilidade natural do solo na ausência da adubação nitrogenada ou com baixas doses de nitrogênio, assim como o curto período do efeito residual de uma aplicação de $75 \mathrm{~kg}$ de nitrogênio por hectare, que apenas resultou em elevada produção de forragem no primeiro corte. $O$ autor também ressalta que o decréscimo da temperatura e a baixa precipitação observados a partir do mês de abril contribuíram para a queda no rendimento 
forrageiro, constatada no terceiro e quarto cortes da gramínea, corroborando os resultados obtidos no presente experimento.

Um dos objetivos principais do experimento foi o de verificar o efeito da adubação nitrogenada no final do período das águas sobre a estacionalidade da produção de matéria seca. Nesse sentido, foram efetuadas análises da produção de matéria seca obtida durante o período das secas (somatórios da produção de matéria seca do primeiro e segundo cortes efetuados em maio e setembro, respectivamente), durante o período do início da primavera (terceiro corte efetuado em novembro) e considerado como intermediário entre o período das secas e das chuvas e para o período das chuvas (quarto e quinto cortes), considerando-se a contribuição percentual de cada um destes períodos sobre $\circ$ total anual. Os resultados obtidos encontram-se na Tabela 6 e na Figura 2.

Observa-se na Tabela 6 e Figura 2 que a aplicação das doses de nitrogênio no final do período das águas, além do efeito já mencionado no aumento da produção de matéria seca, aumentou de 27 para $34 \%$ a proporção de forragem produzida no periodo das secas, quando se elevou a adubação nitrogenada de 60 para $240 \mathrm{~kg}$ por hectare, respectivamente. Se considerarmos o período das secas e do início da primavera (soma dos três primeiros cortes), vê-se que a elevação da proporção da produção de matéria seca é mais significativa, havendo um aumento de 39,13 para $51,01 \%$ entre a menor e maior dose de nitrogênio aplicada, resultando numa expressiva melhoria na distribuição da produção anual do capim-elefante cv. Guaçu. 


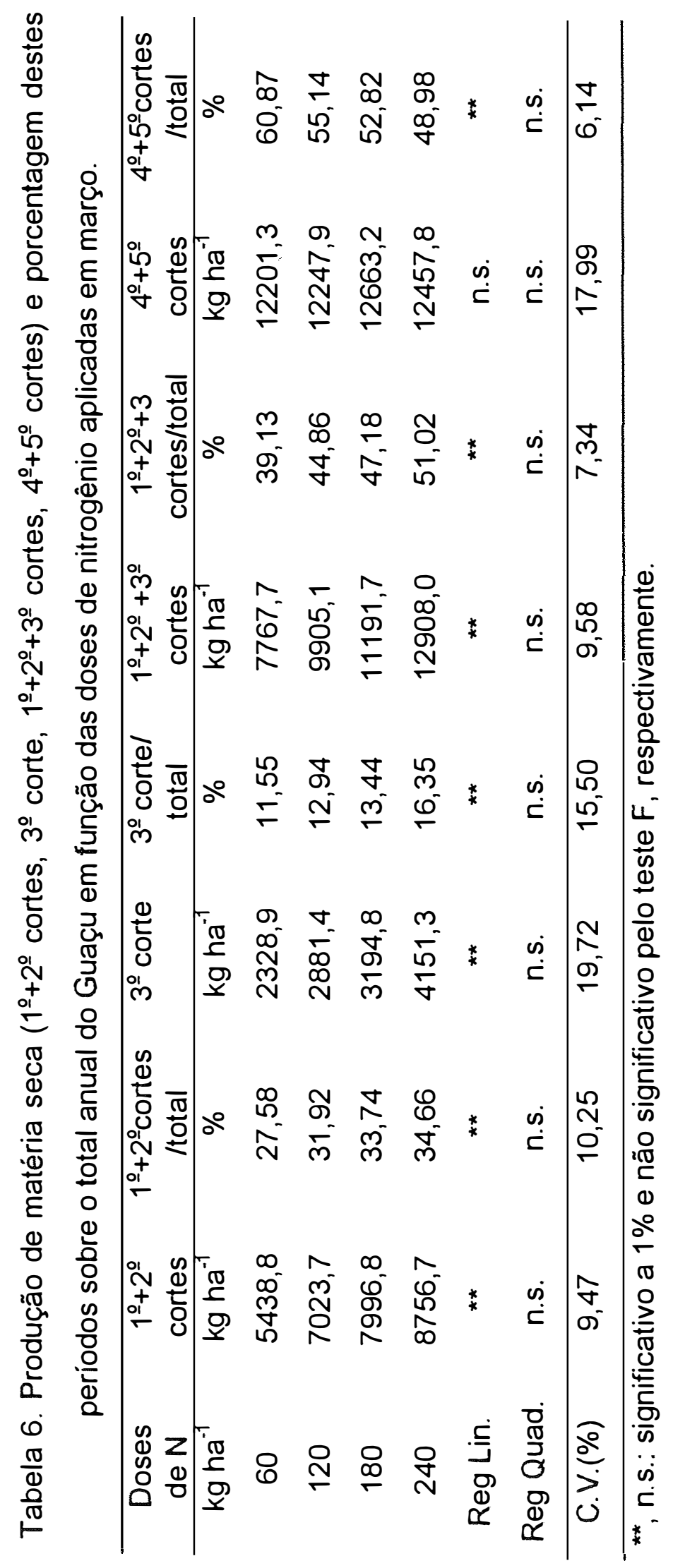




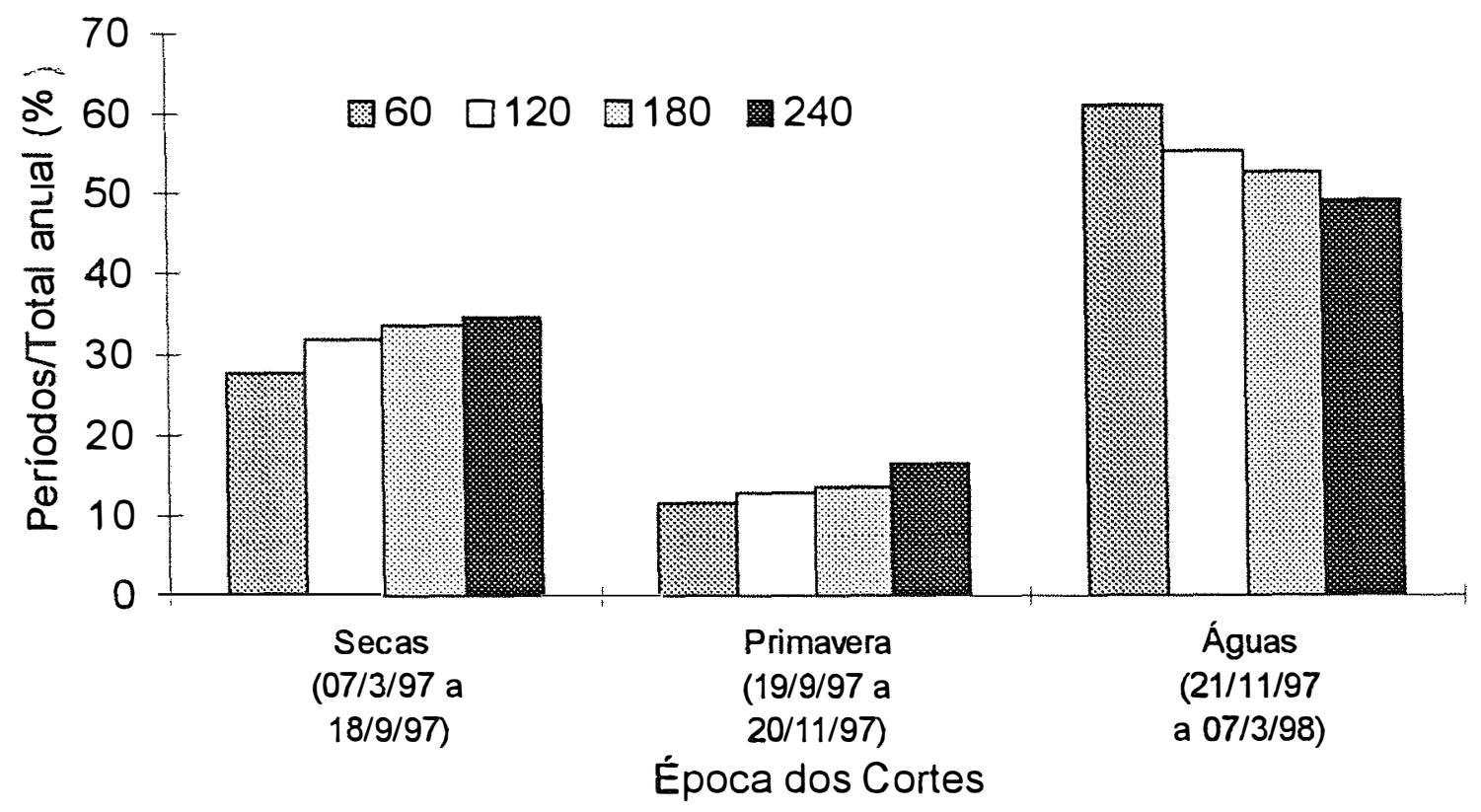

Figura 2. Produções relativas de matéria seca do Guaçu em diferentes períodos do ano, em função das doses de nitrogênio aplicadas em março.

Pedreira \& Mattos (1982), ao estudarem oito cultivares de capimelefante, com cortes a cada seis semanas no período das águas e a cada nove semanas no período das secas e adubando o capim com nitrogênio a cada corte (portanto, maiores quantidades de nitrogênio aplicadas no período das águas), verificaram que a produção nas secas (maio a setembro), variou de 23 a $33 \%$ da quantidade de matéria seca produzida no ano, dependendo do cultivar. Carvalho et al. (1975) também citam que, no periodo das secas, os rendimentos de matéria seca corresponderam a cerca de $30 \%$ dos totais produzidos durante 0 ano, sendo as porcentagens observadas no presente experimento ( 27 a $34 \%$ ) localizadas dentro da faixa relatada pelos autores 
citados, quando se considera a soma dos dois primeiros cortes, ou superiores, quando se inclui o terceiro corte.

Trabalhos conduzidos por Vicente-Chandler \& Figarella (1962), em Porto Rico, mostraram uma distribuição desigual na produção do capim-elefante ao longo do ano. Assim, foram obtidas produções médias de $1.758 \mathrm{~kg}$ por hectare de matéria seca, no quadrimestre em que as temperaturas foram mais amenas, com dias mais curtos e relativamente menor precipitação pluviométrica, comparada com a média de $3.637 \mathrm{~kg}$ por hectare de matéria seca, no quadrimestre favorável ao crescimento do capim, considerando somente uma dose de nitrogênio de $672 \mathrm{~kg}$ por hectare por ano.

Lima et al. (1968) ao avaliarem a produção de carne de bovinos em pastagens de gramíneas, entre elas o capim-elefante Napier, sob dois tratamentos de adubação ( 0 e $200 \mathrm{~kg}$ de nitrogênio por hectare por ano, parcelados em março, maio e setembro), observaram que as áreas fertilizadas de cada gramínea produziram, nos novilhos no periodo das secas, uma taxa de desenvolvimento mais favorável em comparação com pastos não fertilizados. Durante o período das águas, não houve diferença na média do ganho total por novilho entre os pastos fertilizados e não fertilizados. Comparando os resultados de ambos os períodos (chuvas e secas), os autores concluíram que o nitrogênio aplicado durante o período das secas, aumentou a taxa diária de crescimento dos novilhos em relação às forragens não fertilizadas durante aquele período, mas não produziu maiores ganhos na mesma comparação durante o verão.

Werner (1970/71), estudando diversas épocas de aplicação de nitrogênio, no capim-colonião, em sistema de corte, verificou que, embora a produção total de matéria seca tenha sido similar para todas as épocas de adubação, a fertilização com nitrogênio em uma única aplicação em março, ou dividida em duas vezes (com uma das aplicações em março), resultou em maiores percentuais de produção de forragem no periodo das secas, com $21 \%$ 
da produção total anual naquele período, enquanto que a testemunha, além da menor produção total, apresentava somente $12 \%$ da mesma no período seco. Em contraposição, quando todo o nitrogênio era aplicado em setembro, novembro ou janeiro, ocorria a maior concentração da produção de matéria seca do capim no período das águas, porém com baixíssimas produções no período das secas, sem alterar a produção total anual.

Lourenço et al. (1978), comparando o efeito de três doses de adubação nitrogenada $(50,100,150 \mathrm{~kg}$ por hectare), em uma única aplicação feita no final do período chuvoso (março-abril), verificaram que à medida que se aumentou a adubação nitrogenada dentro dos limites utilizados, ocorreram aumentos significativos nos ganhos de peso vivo por hectare e na capacidade de suporte, tanto para o período das águas quanto para o das secas. A aplicação de nitrogênio no final do período chuvoso contribuiu para elevar a produção do capim-elefante cv. Napier no período das secas, que corresponde à época do ano menos favorável ao crescimento de plantas, resultando em maior proporção de produção animal no período das secas à medida em que se aumentou a adubação nitrogenada.

Os dados obtidos no presente trabalho coincidem com aqueles obtidos por Lima et al. (1968), Werner (1970/71) e por Lourenço et al. (1978), descritos anteriormente.

\subsection{Porcentagem de matéria seca}

Não houve influência significativa das doses de nitrogênio sobre a porcentagem de matéria seca do capim-elefante em nenhum dos cortes analisados. Verifica-se que a porcentagem do capim-elefante permaneceu relativamente estável, com valores médios de 13,8 a $18,45 \%$ para todos os cortes, exceto para o segundo corte (efetuado em setembro de 1998), em que a 
porcentagem de matéria seca atingiu valores médios de $26 \%$ (Tabela 7 ). Além do segundo corte ter ocorrido no período mais crítico, com a mais baixa precipitação, acresce-se o efeito da idade de crescimento, uma vez que o segundo corte foi realizado quando a planta apresentava aproximadamente 120 dias de crescimento, enquanto que nos outros periodos os cortes foram realizados quando a planta apresentava cerca de 60 dias de crescimento (exceto o quinto corte em que as plantas foram cortadas com 45 dias).

Tabela 7. Porcentagens de matéria seca do Guaçu, nos cinco cortes, em função das doses de nitrogênio aplicadas em março.

\begin{tabular}{cccccc}
\hline $\begin{array}{c}\text { Doses } \\
\text { de N }\end{array}$ & $\begin{array}{c}1^{\circ} \text { corte } \\
16 / 05 / 97\end{array}$ & $\begin{array}{c}2^{\circ} \text { corte } \\
18 / 09 / 97\end{array}$ & $\begin{array}{c}3^{\circ} \text { corte } \\
20 / 11 / 97\end{array}$ & $\begin{array}{c}4^{\circ} \text { corte } \\
22 / 01 / 98\end{array}$ & $\begin{array}{c}5^{\circ} \text { corte } \\
07 / 03 / 98\end{array}$ \\
\hline kg ha $^{-1}$ & & & $\%$ & & \\
60 & 16,83 & 25,13 & 15,58 & 18,45 & 13,80 \\
120 & 17,21 & 26,07 & 15,86 & 18,45 & 14,20 \\
180 & 17,58 & 26,36 & 15,64 & 18,46 & 14,03 \\
240 & 17,11 & 25,13 & 15,84 & 18,45 & 13,93 \\
Reg Lin. & n.s. & n.s. & n.s. & n.s. & n.s. \\
Reg Quadr. & n.s. & n.s. & n.s. & n.s. & n.s. \\
\hline C.V. (\%) & 4,64 & 4,73 & 6,21 & 5,45 & 4,51 \\
\hline
\end{tabular}

n.s.: não significativo pelo teste $F$.

Resultados semelhantes foram obtidos por diversos autores trabalhando com o capim-elefante, nos quais o aumento da idade por ocasião do corte apresentou acréscimo na porcentagem de matéria seca, variando de 14,4\% na quarta semana para $22,1 \%$ na sexta semana (Devendra, 1975) ou de 17,05 a $34,08 \%$ para as idades de 45 e 195 dias, respectivamente (Prospero, 1972). 


\subsection{Teores de proteina bruta}

Os teores de proteina bruta do Guaçu, nos cinco cortes, são apresentados na Tabela 8. Na figura 3 é representada a variação dos teores de proteína bruta em resposta às doses de nitrogênio aplicadas em março, nos corte em que houve resposta significativa $(P<0,01)$.

Tabela 8. Teores de proteína bruta na matéria seca do Guaçu, nos cinco cortes, em função das doses de nitrogênio aplicadas em março.

\begin{tabular}{|c|c|c|c|c|c|}
\hline Doses & $1^{\circ}$ corte & $2^{0}$ corte & $3^{\circ}$ corte & $4^{\circ}$ corte & $5^{\circ}$ corte \\
\hline de $N$ & $16 / 05 / 97$ & 18/09/97 & $20 / 11 / 97$ & $22 / 01 / 98$ & $07 / 03 / 98$ \\
\hline $\mathrm{kg} \mathrm{ha}^{-1}$ & 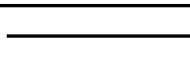 & 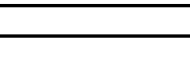 & $\ldots$ & 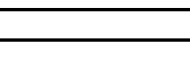 & 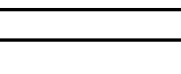 \\
\hline 60 & 6,93 & 4,25 & 5,99 & 5,36 & 9,73 \\
\hline 120 & 8,70 & 4,44 & 5,88 & 5,51 & 9,89 \\
\hline 180 & 10,17 & 4,88 & 6,08 & 5,42 & 9,71 \\
\hline 240 & 10,92 & 5,23 & 6,28 & 5,44 & 9,74 \\
\hline Reg Lin. & ** & $\star \star$ & $\star \star$ & n.s. & n.s. \\
\hline Reg Quadr. & n.s. & n.s. & n.s. & n.s. & n.s. \\
\hline C.V. (\%) & 7,80 & 6,93 & 6,02 & 11,38 & 10,02 \\
\hline
\end{tabular}

Os teores de proteina bruta da parte aérea do Guaçu apresentaram um aumento linear com as doses de nitrogênio para os três primeiros cortes, similarmente ao observado para a produção de matéria seca, o que está de acordo com relatos de Vicente-Chandler et al. (1959), Guerrero et al. (1970) e Paciullo (1997), entre outros autores. Observa-se, no primeiro corte, um incremento de 0,0222 unidades percentuais no teor de proteina bruta da parte aérea do capim Guaçu em resposta à aplicação de cada kg de nitrogênio por 
hectare. Esse incremento no valor protéico encontra-se abaixo do encontrado por Paciullo (1997), cujo aumento foi de 0,0302 unidades percentuais. Ressalta-se, contudo, que o autor observou esse incremento analisando-se somente as folhas, e não a parte aérea como um todo.

Apesar de terem sido observados aumentos estatisticamente significativos $(P<0,01)$ para o segundo e terceiro cortes, observa-se que 0 incremento foi muito mais reduzido, atingindo 0,006 e 0,002 unidades percentuais no teor de proteína bruta, para o segundo e terceiro cortes, respectivamente, em resposta à aplicação de cada $\mathrm{kg}$ de nitrogênio por hectare.

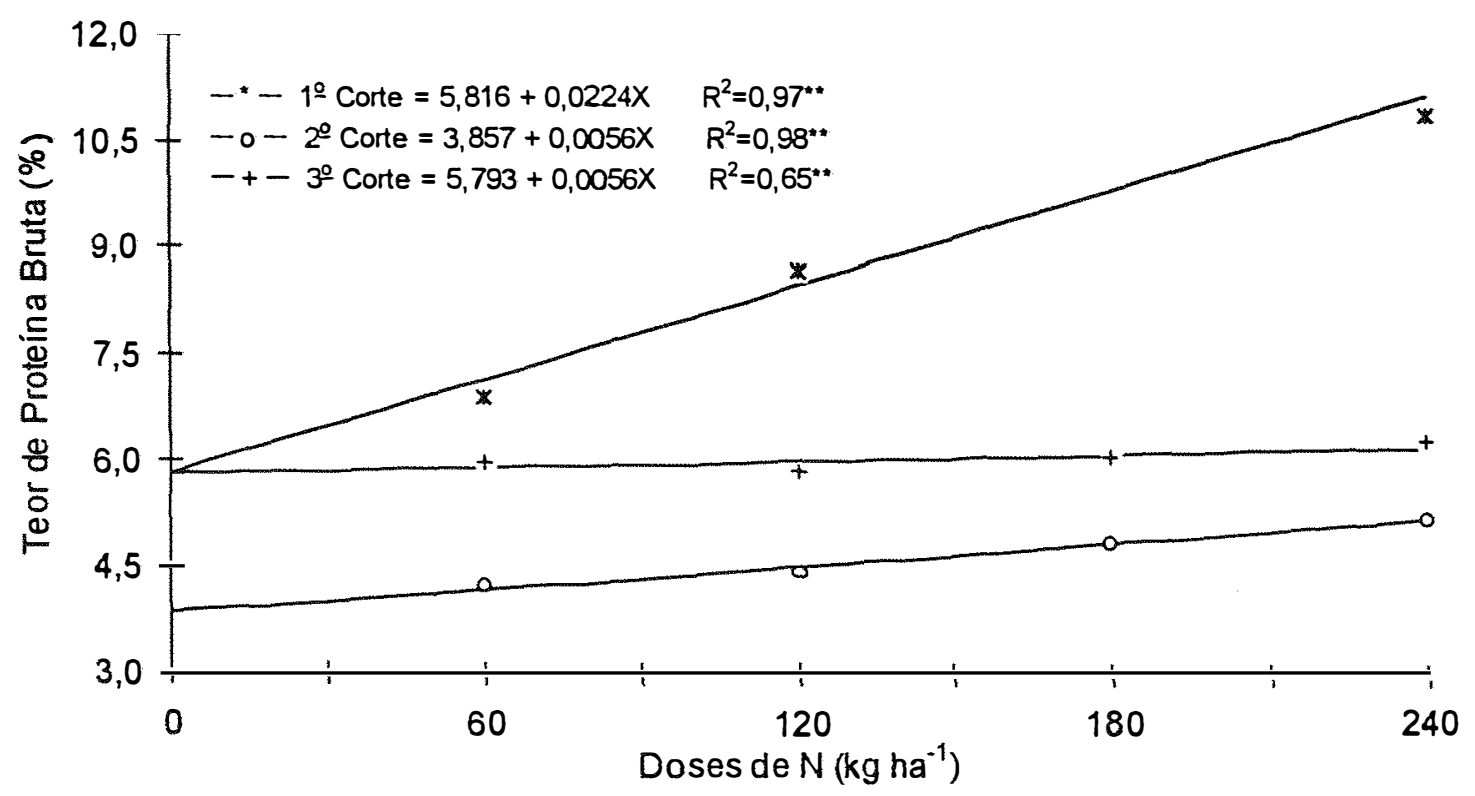

Figura 3. Teores de proteína bruta do Guaçu no primeiro, segundo e terceiro cortes, em função das doses de nitrogênio aplicadas em março.

Os teores médios de proteína bruta na parte aérea do Guaçu variaram de 4,25 na dose mais baixa de nitrogênio e época mais crítica a $10,92 \%$ para a dose mais elevada (Tabela 8 ). Teores mais elevados foram verificados no 
primeiro e quinto cortes. No primeiro, por se tratar do corte efetuado após a aplicação das doses de nitrogênio e periodo em que as temperaturas já começavam a cair, resultando em crescimento menos acelerado do capim. No quinto corte, por se tratar de crescimento em época de condições de maior temperatura e precipitação, conjugado com o menor período de crescimento (45 dias) entre os cinco cortes efetuados, além de realizado após uma adubação igual de $60 \mathrm{~kg}$ de nitrogênio por hectare para todos os tratamentos. Fato similar foi destacado para o colonião por Werner et al. (1970/71), em que, a cada corte (realizado com 60 dias de crescimento), os tratamentos que recebiam adubação imediatamente ao corte anterior, apresentavam os mais elevados teores de proteina em relação aos outros tratamentos.

Resultados de Werner et al. (1967) com capim pangola mostram que o nitrogênio aplicado em doses pequenas a moderadas, atua principalmente, no aumento do crescimento e da produtividade da gramínea. Só com adubações nitrogenadas bastante elevadas é que se consegue aumentar acentuadamente o teor de proteina na forragem, o que ficou comprovado pelos resultados obtidos no presente experimento, em que aumento acentuado somente foi verificado quando se aumentou a dose de 60 para 180 ou $240 \mathrm{~kg}$ de nitrogênio por hectare em março.

Um nivel adequado de nitrogênio na forragem é essencial para se garantir elevado consumo voluntário pelo animal. Milford \& Minson (1966) demonstraram que o consumo de matéria seca das forrageiras tropicais foi positivamente influenciado pelo teor protéico do pasto até o nivel de $7 \%$, permanecendo inalterado para teores de proteina acima desse valor. Os teores médios de proteína bruta da planta inteira do Guaçu mantiveram-se acima do valor crítico de $7 \%$ (Milford \& Minson, 1966) somente no primeiro e quarto cortes.

Apesar de o delineamento experimental adotado não ter permitido a comparação entre cortes verificou-se, no presente experimento, que os teores 
de proteína bruta foram mais elevados no primeiro corte, decorrente do efeito da adubação nitrogenada. No segundo corte, em função da baixa precipitação, a planta não conseguiu absorver o nitrogênio presente no solo em quantidade suficiente, apresentando consequentemente um baixo teor de proteína bruta, conjugado com baixa produção. A partir do terceiro corte, com maior umidade no solo, houve novamente elevação no teor de proteína bruta, mas que não foi suficiente para que a planta atingisse o nível crítico mínimo de $7 \%$ estabelecido por Milford \& Minson (1966) para atendimento das exigências do animal. Os valores de produção de matéria seca (Tabela 5) e os teores de proteína bruta (Tabela 8) apresentaram correlação significativa somente no primeiro e segundo cortes ( $r=0,80^{\star \star}$ e $0,36^{\star \star}$, respectivamente)

Os teores de proteína bruta no quarto e quinto cortes apresentam-se inversamente relacionados à produção de matéria seca. Uma maior produção de matéria seca observada no quarto corte foi acompanhada de mais baixo teor de proteína bruta, comparativamente ao teor da mesma no quinto corte. Esses valores podem ser atribuídos a um efeito de diluição no quarto corte, decorrente da maior produção de matéria seca observada. Efeito de diluição foi também observado por Pacciulo (1997).

Werner et al. (1967), estudando o parcelamento e níveis de adubação nitrogenada em capim pangola, relatou que o teor médio de proteína bruta na matéria seca da gramínea elevou-se à medida que se aumentou a adubação nitrogenada, chegando quase a dobrar o seu teor, variando de 6,84\% na testemunha sem nitrogênio, até 11,34 e 12,82\%, respectivamente para $400 \mathrm{~kg}$ de nitrogênio aplicado de uma só vez e em dois parcelamentos.

\subsection{Extração de nitrogênio}

A quantidade de nitrogênio retirada pelo capim Guaçu, calculada em função da concentração de nitrogênio na parte aérea e da produção de matéria 
seca da gramínea, apresentou efeito significativo $(P<0,01)$ das doses de nitrogênio para o primeiro, segundo e terceiro cortes, segundo um modelo linear para os mesmos, conforme pode ser verificado na Figura 4.

O capim-elefante é uma planta exigente em nutrientes, em decorrência de seu elevado potencial de produção, sendo, via de regra, a extração de nutrientes do solo, pela forrageira, proporcional aos rendimentos obtidos. Com manejo intensivo, normalmente verifica-se uma remoção apreciável de nutrientes, em especial o nitrogênio.

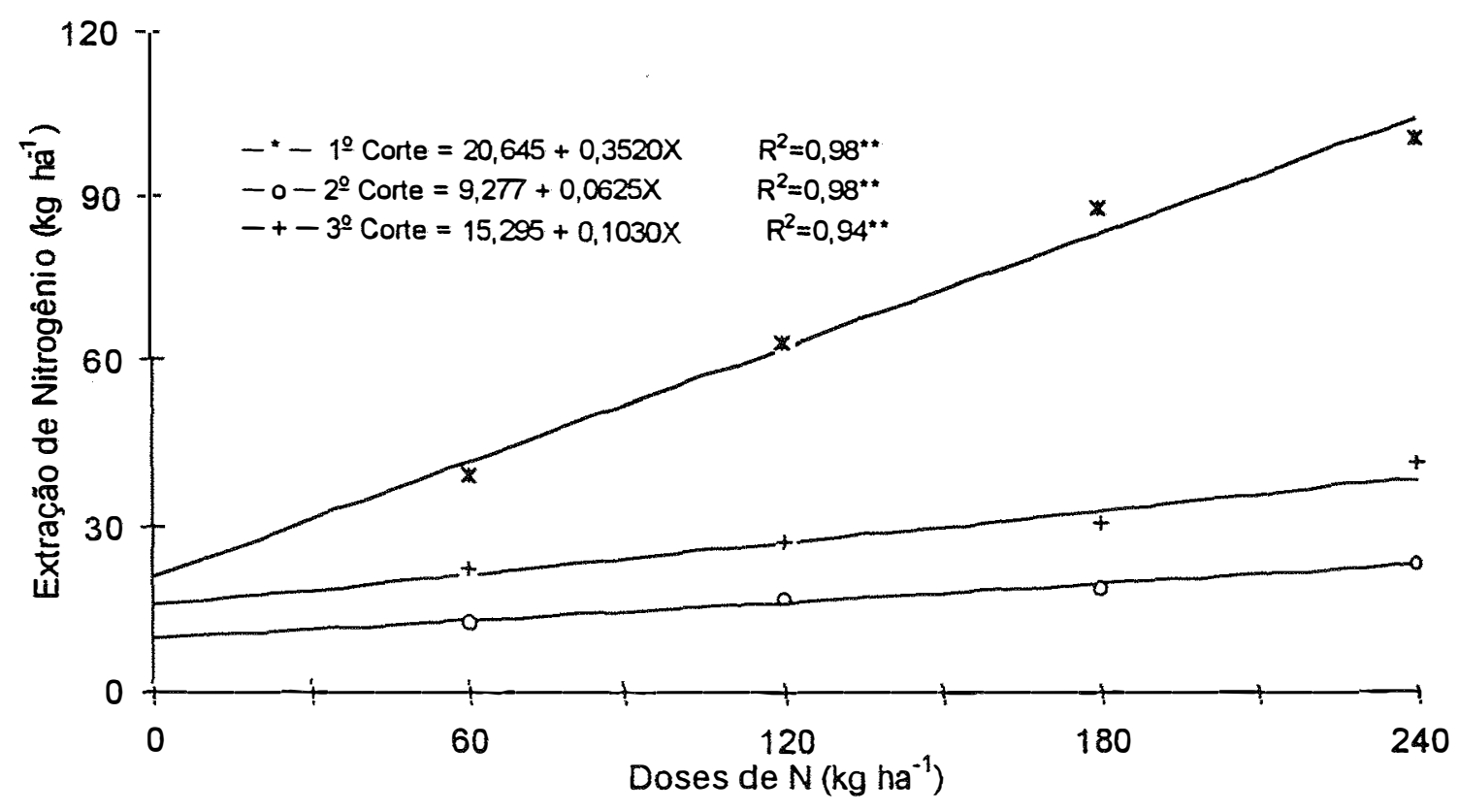

Figura 4. Extração de nitrogênio do Guaçu no primeiro, segundo e terceiro cortes, em função das doses de nitrogênio aplicadas em março.

Considerando-se o total de nitrogênio extraído pelo Guaçu no período de um ano, verifica-se que este variou de 213 a $310 \mathrm{~kg}$ de nitrogênio por hectare (Tabela 9) para uma produção total de matéria seca de cerca de 20 a 25 toneladas por hectare por ano, estando abaixo do citado por Carvalho 
(1985), o qual indica que a planta extraiu um mínimo de 450 e um máximo de $840 \mathrm{~kg}$ para uma produção de 30 toneladas de matéria seca de capim-elefante. Já Vicente-Chandler et al. (1974) encontraram uma remoção de nitrogênio de $338 \mathrm{~kg}$ por hectare por ano, ainda superior a extração no presente experimento.

Tabela 9. Extração de nitrogênio do Guaçu, nos cinco cortes e no total dos cortes, em função das doses de nitrogênio aplicadas.

\begin{tabular}{|c|c|c|c|c|c|c|}
\hline Doses & $1^{\circ}$ corte & $2^{\circ}$ corte & $3^{\circ}$ corte & $4^{\circ}$ corte & $5^{\circ}$ corte & Total \\
\hline de $N$ & $16 / 05 / 97$ & $18 / 09 / 97$ & $20 / 11 / 97$ & $22 / 01 / 98$ & 07/03/98 & \\
\hline $\mathrm{kg} \mathrm{ha}^{-1}$ & & & k & $h a^{-1} \quad \cdots$ & & \\
\hline 60 & 39,52 & 12,78 & 22,32 & 65,52 & 74,94 & 213,28 \\
\hline 120 & 63,95 & 17,52 & 27,73 & 64,47 & 77,36 & 252,67 \\
\hline 180 & 88,67 & 19,78 & 31,08 & 67,57 & 79,00 & 284,45 \\
\hline 240 & 101,76 & 24,52 & 41,76 & 67,33 & 73,14 & 310,32 \\
\hline Reg Lin & 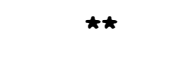 & $\star \star$ & 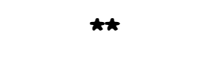 & n.s. & n.s. & $\star \star$ \\
\hline Reg Quadr. & n.s. & n.s. & n.s. & n.s. & n.s. & n.s. \\
\hline C.V. (\%) & 14,79 & 15,76 & 23,23 & 30,39 & 19,97 & 16,60 \\
\hline
\end{tabular}

${ }^{\star \star}$, n.S.: significativo a $1 \%$ e não significativo pelo teste $F$, respectivamente.

Pelos dados da Tabela 9, nota-se que nas duas doses mais baixas de nitrogênio (60 e $120 \mathrm{~kg}$ aplicadas em março, mais duas aplicações de $60 \mathrm{~kg}$ em novembro e janeiro) a extração de nitrogênio foi maior que as quantidades aplicadas. Ao contrário, nas duas doses mais elevadas (180 e $240 \mathrm{~kg}$ de nitrogênio em março, também seguidas por duas aplicações de $60 \mathrm{~kg}$ em novembro e janeiro) as extrações foram menores que as aplicações. Isto provavelmente ocorreu devido a maior utilização pelo Guaçu do nitrogênio aplicado e também do nitrogênio presente do solo, nas doses mais baixas e/ou maiores perdas do nitrogênio aplicado nas doses mais elevadas, 
principalmente por se tratar de um terreno arenoso. Isto caracteriza uma perda progressiva do potencial de fornecimento de nitrogênio do solo, na ausência ou na presença da aplicação de doses baixas de nitrogênio, como verificado por Pacciullo (1997) também trabalhando com capim-elefante adubado com doses de 0 a $300 \mathrm{~kg}$ de nitrogênio por hectare por ano.

\subsection{Altura da planta}

A altura média das plantas do Guaçu, medida por ocasião dos cortes apresentou diferença significativa $(P<0,01)$ entre as doses de nitrogênio aplicadas em março, para o primeiro, segundo e terceiro cortes, segundo um modelo linear para todos eles, conforme pode ser verificado na Figura 5. Para o quarto e quinto cortes não houve diferença significativa entre os tratamentos.

As alturas das plantas observadas em cada corte, além de variarem com as doses de nitrogênio aplicadas e épocas de corte (Tabela 10) apresentaram relação com as respectivas produções de matéria seca (Tabela 5), exceto no quinto corte, fato relatado por Boin et al. (1974), que citam ter o rendimento de matéria seca do capim elefante Napier, em cada corte, estreita relação com a altura do "stand" na hora do corte. Os coeficientes de correlação entre altura e produção de matéria seca foram de $0,84^{\star \star} ; 0,71^{\star \star} ; 0,85^{\star \star}$ e $0,48^{\star *}$, respectivamente para o primeiro, segundo, terceiro e quarto cortes. 


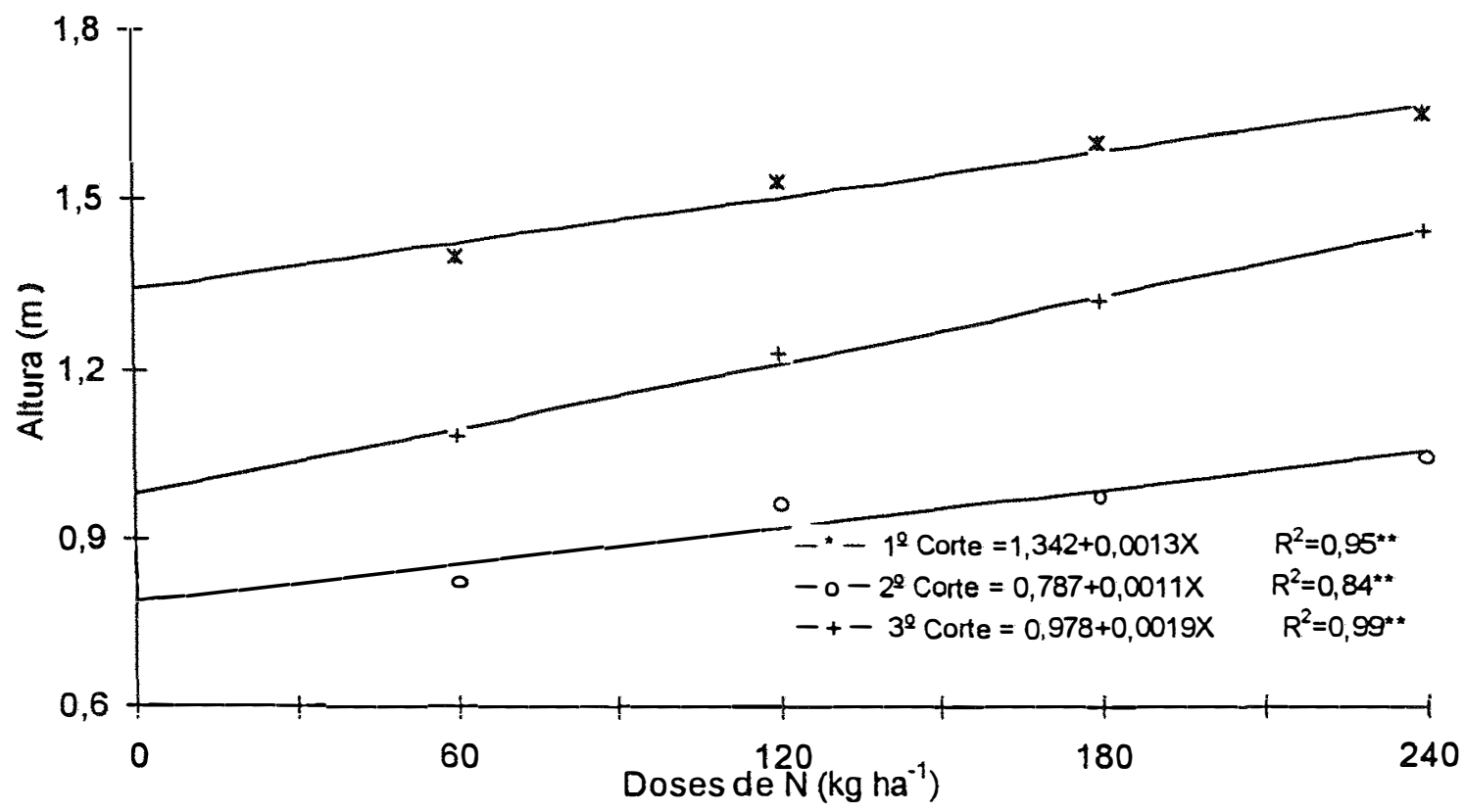

Figura 5. Altura do Guaçu, por ocasião do primeiro, segundo e terceiro cortes, em função das doses de nitrogênio aplicadas em março.

Tabela 10. Altura do Guaçu, nos cinco cortes, em função das doses de nitrogênio aplicadas em março.

\begin{tabular}{cccccc}
\hline $\begin{array}{c}\text { Doses } \\
\text { de N }\end{array}$ & $\begin{array}{c}\text { Corte 1 } \\
16 / 05 / 97\end{array}$ & $\begin{array}{c}\text { Corte 2 } \\
18 / 09 / 97\end{array}$ & $\begin{array}{c}\text { Corte 3 } \\
20 / 11 / 97\end{array}$ & $\begin{array}{c}\text { Corte 4 } \\
22 / 01 / 98\end{array}$ & $\begin{array}{c}\text { Corte 5 } \\
07 / 03 / 98\end{array}$ \\
\cline { 2 - 5 } $\mathrm{kg} \mathrm{ha}^{-1}$ & & & $\mathrm{~m}$ & & \\
60 & 1,40 & 0,82 & 1,08 & 1,68 & 1,31 \\
120 & 1,53 & 0,96 & 1,23 & 1,77 & 1,37 \\
180 & 1,60 & 0,97 & 1,32 & 1,75 & 1,35 \\
240 & 1,65 & 1,05 & 1,44 & 1,76 & 1,37 \\
Reg Lin. & $\star \star$ & $\star \star$ & $\star \star$ & n.s. & n.s. \\
Reg Quadr. & n.s. & n.s. & n.s. & n.s. & n.s. \\
\hline C.V. (\%) & 6,94 & 9,57 & 12,94 & 5,69 & 5,08
\end{tabular}

**, n.s.: significativo a $1 \%$ e não significativo pelo teste $F$. 


\section{CONCLUSÕES}

A aplicação de doses de nitrogênio no final do período das águas (março) proporcionou aumentos lineares na produção de matéria seca nos três primeiros cortes (maio, setembro e novembro) e no total anual.

A adubação com nitrogênio em março aumentou de 27 para $34 \%$ a proporção de forragem produzida no período das secas (março a setembro), quando se elevou a adubação nitrogenada de 60 para $240 \mathrm{~kg}$ por hectare, respectivamente.

A porcentagem de matéria seca do Guaçu não foi afetada pelas doses de nitrogênio aplicadas em março.

Os teores de proteína bruta, altura da planta e a extração de nitrogênio pelo Guaçu aumentaram em função das doses de nitrogênio aplicadas em março nos três primeiros cortes, não sendo afetadas nos dois últimos cortes. 


\section{REFERÊNCIAS BIBLIOGRÁFICAS}

ALCANTARA, P.B.; ALCANTARA, V.B.G.; ALMEIDA, J.E. Estudo de vinte e cinco prováveis variedades de capim-elefante (Pennisetum purpureum Schum.). Boletim de Indústria Animal, v.37, n.2, p.279-302, 1980.

BOIN, C.; PEDREIRA, J.V.S.; CAMPOS, B.do E.S. Rendimento e manejo de capineira de capim-elefante napier (Pennisetum purpureum, Schum.). Boletim da Indústria Animal, Nova Odessa, v.31, n.2, p.293-299, 1974.

BUTTER WORTH, M.; ARIAS, P.J. Nutritive value of elephant grass cut at various ages. In: INTERNATIONAL GRASSLAND CONGRESS, 9, 1965, São Paulo. Proceedings. São Paulo: Secretaria da Agricultura, 1966. p. 899-901.

CARO COSTAS, R.; VICENTE-CHANDLER, J. Comparative productivity of Mercker grass and of Kudzu Mercker grass mixture as affected by season and cutting height. Journal of Agriculture of the University of Puerto Rico, v.40, p.144-151, 1956.

CARVALHO, L.A. Pennisetum purpureum Schumach: revisão. Coronel Pacheco, EMBRAPA-CNPGL, 1985. 86p. (Boletim de Pesquisa, 9). 
CARVALHO, M.M. Melhoramento da produtividade das pastagens através da adubação. Informe Agropecuário, v.11, p.23-32, 1985.

CARVALHO, L.de A.; MARTINS, M.S.; SALDANHA, E.M. Bibliografia de Pennisetum purpureum, Schum. Brasilia: EMBRAPA, 1982. 380p.

CARVALHO, S.R.; SILVA, A.T.; COSTA, F.A.; SOUTO, S.M.; LUCAS, E.D. Influência da irrigação e da adubação em dois cultivares de capim-elefante (Pennisetum purpureum Schum). Pesquisa Agropecuária Brasileira, v.10, n. 4, p.23-30, 1975.

CORSI, M. O clima e a produção de forragem. In: SIMPÓSIO SOBRE MANEJO DA PASTAGeM, 1, Piracicaba, 1973. Anais. Piracicaba: ESALQ/USP, 1973. p.181-204.

CORSI, M.; NUSSIO, L.G. Manejo do capim-elefante: correção e adubação do solo. In: SIMPÓSIO SOBRE MANEJO DA PASTAGEM, 10, Piracicaba, 1992. Anais. Piracicaba: FEALQ, 1994. p.87-115.

DEVENDRA, C. The intake and digestibility of napier grass (Pennisetum purpureum) at four, five and six weeks of growth by goats and sheep in Trinidad. Turrialba, v.25, n.3, p.226-231, 1975.

FARIA, V.P.de. Efeito da maturidade da planta e diferentes tratamentos sobre a ensilagem do capim elefante (Pennisetum purpureum Schum.) variedade Napier. Piracicaba: ESALQ, 1971. 78p. (Tese- Douturado). 
FARIA, V.P.de. Formas de uso do capim-elefante. In: SIMPÓSIO SOBRE CAPIM-ELEFANTE, 2, Coronel Pacheco, 1994. Anais. Coronel Pacheco: EMBRAPA/CNPGL, 1994. p.139-148.

GHISI, O.M.A.A. et al. Avaliação do capim-elefante (Pennisetum purpureum cv Guaçu), visando o carvoejamento. Relatório Final, Instituto de Zootecnia, 1995. 45p.

GOMES, I.; MENENDEZ, J.; CORDOVI, E. Evaluacion de especies del genero Pennisetum em condiciones de corte. In: Primer Seminario Cientifico Tecnico, Provincia de Las Tunas, 18 al 20 de maio de 1978. Tomo 1. In: Herbage Abstracts, Hurley, Berks, v.50, n.11, p. 4989, 1980.

GONÇALEZ, D.A.; VIANA, J.A.C.; MOREIRA, H.A. Produção de dois cultivares de Pennisetum purpureum, Schum, submetido a dois niveis de fertilidade em diferentes estações do ano. Arq Escola de Veterinária UFMG, v.29, n. 2, p.153-160, 1977.

GOMIDE, J.A. Formação e utilização de capineira de capim elefante. In: SIMPÓSIO SOBRE CAPIM-ELEFANTE, Coronel Pacheco, 1990. Anais. Coronel Pacheco: EMBRAPAVNPGL, 1990. p.59-87.

GUERRERO, R.; FASSBENDER, H.W.; BLYDENSTEIN, J. Fertilization del pasto elefante (Pennisetum purpureum) en Turrialba, Costa Rica. I. Efecto de dosis crecientes de nitrogeno. Turrialba, v.20, n.1, p.53-58, 1970.

HILLESHEIM, A. Manejo do capim-elefante. In: SIMPÓSIO SOBRE MANEJO DA PASTAGEM, 10, Piracicaba, 1992. Anais. Piracicaba: FEALQ, 1994. p.117-141. 
JACQUES, A.V.A. Fisiologia do crescimento do capim-elefante. In: SIMPÓSIO SOBRE CAPIM-ELEFANTE. Coronel Pacheco, 1990. Anais. Coronel Pacheco: EMBRAPA/CNPGL, 1990. 195p.

LAVEZZO, W. Ensilagem de capim elefante. In: SIMPÓSIO SOBRE MANEJO DA PASTAGEM, 10, Piracicaba, 1992. Anais. Piracicaba: FEALQ, 1994. p.169-275.

LIMA, F.P.; MARTINELLI, D.; WERNER, J.C. Produção de carne bovina em pastagens de gramíneas em região de terras roxas (Latossol Roxo). Boletim da Indústria Animal, v.25, p.129-137, 1968.

LONERAGAN, J.F. The nutrition of grasslands. In: BARNARD, C., ed. Grasses and grasslands. Canberra: C.S.I.R.O, Division of Plant Nutrition, 1964. p.206-220.

LOURENÇO, A.J.; SARTINI, H.J.; SANTA MARIA, M.; et al. Estudo comparativo entre três níveis de fertilização nitrogenada e consorciada com leguminosas em pastagens de capim-elefante Napier (Pennisetum purpureum, Schum.) na determinação da capacidade de suporte. Boletim da Indústria Animal, v.35, p.69-80, 1978.

MALAVOLTA, E.; HAAG, H.P.; MELLO, F.A.F.; BRASIL SOBRINHO, M.O.C. Nutrição mineral e adubação de plantas cultivadas. São Paulo, Pioneira, 1974. 727p. 
MARTINS, C.E.; FONSECA, D.M.da. Manejo de solo e adubação de pastagem de capim-elefante. In: SIMPÓSIO SOBRE CAPIM-ELEFANTE, Coronel Pacheco, 2, 1994. Anais. Coronel Pacheco: EMBRAPA/CNPGL, 1994. p.82-115.

MILFORD, R.; MINSON, D.J. Intake of tropical pastures species. In: CONGRESSO INTERNACIONAL DE PASTAGENS, 9, São Paulo, 1965. Anais. São Paulo: Secretaria da Agricultura, 1966. V.1, p.814-822.

MONTEIRO, F.A. Adubação para estabelecimento e manutenção de capimelefante. In: SIMPÓSIO SOBRE CAPIM-ELEFANTE. Coronel Pacheco, 1990. Anais. Coronel Pacheco: EMBRAPA/CNPGL, 199, 1990. p.49-79.

MOZZER, O.L.; SIQUEIRA, C.; NOVAES, L.P. Capineira: formação e utilização. $3^{\circ}$ Curso de Pecuária Leiteira. São Paulo: Cia Nestlé, 2.ed., 1986. 163p.

PACIULLO, D.S.C. Produtividade e valor nutritivo do capim-elefante anão (Pennistum purpureum Schum cv. Mott) ao atingir 80 e $120 \mathrm{~cm}$ de altura sob diferentes doses de nitrogênio. Viçosa, 1997. 60 p. (Dissertação Mestrado em Zootecnia).

PEDREIRA, J.V.S.; MATTOS, H.B.de. Crescimento estacional de cultivares de capim-elefante. Boletim da Indústria Animal, Nova Odessa, v.39, n.1, p.29-41, 1982. 
PEDREIRA, J.V.S.; MATTOS, H.B.de. Crescimento estacional dos capinselefante, cv. napier, Pennisetum purpureum, Schum. e guatemala, Tripsacum fasciculatum, Trin.. Boletim da Indústria Animal, v.33, n.2, p.233-242, 1976.

PEREIRA, R.M.M.; SYKES, D.J.; GOMIDE, J.A; VIDIGAL, G.T.. Competição de dez gramíneas para capineira, no cerrado, em 1965. Revista Ceres, v.13, n.74, p.141-153, 1966.

PROSPERO, A.O. Variação estacional da composição química bromatológica, do teor de macronutrientes minerais e da digestibilidade "in vitro" do capim-elefante (Pennisetum prupureum Schum.) variedade napier. Anais da ESALQ, v.29, p.45-51, 1972.

QUINN, L.R.; MOTT, G.O.; BISSCHOFF, W.V.A. Fertilização de pastos de capim colonião e produção de carne com novilhos zebu. New York: IBEC Research Institute., 1961. 40p. (Boletim, 24).

ROLIN, F.A. Estacionalidade de produção forrageira. In: PEIXOTO, A.M.; MOURA, J.C. de; FARIA, V.P. de (Ed.). Pastagens: fundamentos da exploração racional. Piracicaba: FEALQ, 1986. 458p.

RUIZ, M.; SANCHEZ, W.K.; STAPLES, C.R. Comparison of "mott dary elephant grass silage and corn silage for lacting dairy cows. Journal Dairy Science, v.75, n.2, p.533-543, 1992.

SARRUGE, J.R.; HAAG, H.P. Análises quimicas em plantas. Piracicaba: Escola Superior de Agricultura "Luiz de Queiroz", 1974. 56p. 
SILVEIRA, A.C. Contribuição para o estudo do capim-elefante (Pennisetum purpureum, Schum.) como reserva forrageira no trópico. Botucatu, 1976. 234p. Tese de Livre Docência.

VICENTE-CHANDLER, J. Intensive grassland management of tropical forages in Puerto Rico. Revista da Sociedade Brasileira de Zootecnia, Viçosa, v. 2, n.2, p.173-215, 1973.

VICENTE-CHANDLER, J.; ABRUÑA, F.; CARO-COSTA, R.; FIGARELLA, J.; SILVA, $S$. Intensive grassland management in the humid tropics of Puerto Rico. Puerto Rico: University Puerto Rico - Agricultura Experimental Station, 1974. 223p.

VICENTE-CHANDLER, J.; FIGARELLA, J. Effects of five nitrogen souces on yields and composition of napier grass. Journal of Agriculture of the University of Puerto Rico, v.46, n.2, p.102-106, 1962.

VICENTE-CHANDLER, J.; SILVA, S.; FIGARELLA, J. Effects of nitrogen fertilization and frequency of cutting on the yield and composition of napier grass in Puerto Rico. Journal of Agriculture of the University of Puerto Rico, v.43, n.4, p.215-227, 1959.

VIEIRA, L.M.; GOMIDE, J.A. Composição química e produção forrageira de três variedades de capim-elefante. Revista Ceres, v.15, n.86, p.245-260, 1968.

VIETS, F.G. Fertilizer and the efficient use of water. Advances in Agronomy, v.14, p.223-264, 1962. 
WERNER, J.C. Adubação de pastagens. 2 impr. Nova Odessa: Instituto de Zootecnia, 1986. 49p. (Boletim Técnico, 28)

WERNER, J.C. Estudo de épocas da adubação nitrogenada em capim colonião (Panicum maximum Jacq.) para aumento de produção de forragens nas secas. Boletim da Indústria Animal, v. 27/28 (Único), p. 361$367,1970 / 71$.

WERNER, J.C.; PEDREIRA, J.V.S.; CAIELLI, E.L. Estudos de parcelamento e níveis de adubação nitrogenada em capim pangola (Digitaria decumbens Stent.). Boletim de Indústria Animal, v.24, único, p. 147-154, 1967.

WERNER, J.C.; COBRA NETO, A.; COBRA, A.P. Aplicação de amônia anidra em pastagem capim pangola, Digitaria decumbens Stent. Boletim de Indústria Animal, v.31, n.1, p. 97-106, 1974.

ZUNIGA, M.P.; SYKES, D.J.; GOMIDE, J.A. Competição de treze gramíneas forrageiras para corte, com e sem adubação, em Viçosa, Minas Gerais. Revista Ceres, v.13, n.77, p.324-343, 1967.

YEO, Y. Efeito da maturidade do capim-elefante (Pennisetum purpureum Schum.) variedade Napier, sobre sua produção e valor nutritivo. Piracicaba: ESALQ, 1977. 96p. Dissertação-Mestrado. 